\title{
Trends and risk factors of maternal mortality in late-nineteenth-century Netherlands
}

Published as: Ory, B. E., \& Van Poppel, F. W. (2013). Trends and risk factors of maternal mortality in late-nineteenth-century Netherlands. The History of the Family, 18(4), 481-509.

\section{B.E. Ory ${ }^{1 \mathrm{a}}$ and F.W.A. van Poppel ${ }^{\mathrm{b}}$}

${ }^{a}$ Netherlands Interdisciplinary Demographic Institute, Postbus 11650, 2502 AR the Hague, the Netherlands, tel: +31 6104243 53, b.e.ory@uu.nl; Department of Sociology, Utrecht University, Utrecht, the Netherlands;

${ }^{b}$ Netherlands Interdisciplinary Demographic Institute, Postbus 11650, 2502 AR the Hague, the Netherlands, tel: +31 7035652 41, fax + 31.70.3647187; poppel@nidi.nl; Department of Sociology, Utrecht University, Utrecht, the Netherlands

\footnotetext{
$1 *$ Corresponding author. Email: b.e.ory@uu.nl
} 


\title{
Trends and risk factors of maternal mortality in late-nineteenth-century Netherlands
}

\author{
Using family reconstitution data from the Dutch provinces of Groningen, Drenthe, and \\ Zeeland, trends and risk factors of maternal death from 1846 to 1902 are studied. Findings \\ confirm other studies of maternal mortality trends for the Netherlands in the last quarter of \\ the nineteenth century and show that rates were already steadily decreasing in the mid- \\ nineteenth century. The role of biological and social risk factors including age, parity, birth \\ interval, social class, season, and year of giving birth were also explored. Among \\ biological factors we find an increased risk of maternal death for short birth intervals, late \\ maternal age, high and low parity, multiple gestations, and stillbirths. Social factors \\ associated with increase risk are belonging to the skilled working class, being a farmer, \\ giving birth in winter or spring, and giving birth in earlier years. We also explore trends in \\ the data which reveal directions for future research.
}

Keywords: childbirth; family reconstitution; maternal mortality; nineteenth century

\section{Introduction}

Deaths due to pregnancy and childbirth claim the lives of 800 women daily, $99 \%$ of whom live in developing countries (World Health Organisation, 2012). Because of this discrepancy in maternal mortality rates between developed and developing countries, maternal mortality has been called a "societal" rather than an individual indicator of poverty (Andersson, Bergstrom, \& Hogberg, 2000). As such, maternal mortality can be a useful yardstick for national progress. Maternal death reveals not only the standard of living in a country (Andersson et al., 2000; Shepherd, Schoonheim, Tian-Yun, \& Kok, 2011) but also women's position in that society (Khlat \& Guillaume, 2006; Shorter, 1982). Traditional measures of well-being such as average life expectancy and per capita GDP may not be applicable to childbearing women (Ward, 2003). Other causes of death, such as infant mortality (Antonovsky, 1967; Frans Van Poppel, Jonker, \& 
Mandemakers, 2005), are more frequent among lower social classes, but childbirth claims lives across social classes (Irvine Loudon, 1986) and is therefore not easily described by other wellbeing measures. Maternal mortality is not often used as an indicator of the position of women, but it provides unique insight not available in other indicators.

This paper seeks to explore the trends of maternal mortality in three provinces in the Netherlands during the nineteenth century both in terms of tracking the maternal mortality rate through previously unexplored decades and by establishing some of the historical risk factors of maternal mortality.

National cause-of-death statistics have only been issued in the Netherlands since 1865 (Neurdenburg, 1925); however, birth, death, and marriage certificates have been issued in a standardized format on a national scale since 1811. With the help of a new database linking these registries, the Linking System for Historical Family Reconstruction (LINKS), it is now possible to use family reconstitution techniques to approximately measure maternal mortality in the provinces of Groningen, Drenthe, and Zeeland prior to 1865 as the death of any woman within a given time period of childbirth. Despite certain drawbacks of this method of measurement, namely that some non-maternal deaths are falsely attributed to parturition while some true maternal deaths are ignored, this method can be effective where cause of death statistics are unavailable and the population is not available for survey (Kippen, 2005; Schofield, 1986).

This dataset provides a unique opportunity to accurately estimate maternal mortality for 
several reasons. First, it completely covers the population ${ }^{2}$ and is not a survey. Surveys done on current populations to determine recent deaths in respondents' or respondents' sisters' households often have to be conducted on prohibitively large samples (World Health Organisation, 1997) or rely on estimation techniques to adjust for underreporting of deaths or births (Stanton et al., 2001). By contrast, because the LINKS data accesses birth, death, and marriage records for the entire population, any error is due to failure to register a vital event rather than sampling error or sample size. Second, it describes over a million birth events across a century. With maternal mortality being such a rare event, it is useful to have information on many at-risk cases because, through random chance alone, the trend can appear to fluctuate quite a bit in small populations. Third, LINKS includes stillbirth information. This is important because stillbirths are consistently found to be a strong risk factor in maternal mortality studies. Stillbirths include true fetal deaths and live-born children who died before the birth certificate was issued. Many other countries did not start recording stillbirths of any kind until the 1920s and 30s (I. Loudon, 1992; Schofield, 1986). Consequently, many maternal deaths would go unnoticed in a family reconstitution study. Finally, occupations were recorded on vital registers, and as a result it is possible to examine the relationship between social class and maternal mortality. However, the database that we deduced from LINKS has no information on children born out of wedlock as married couples were the starting point of our reconstitution; therefore, this at-risk segment of the population is unavailable for study. It is unclear how much this omission would bias results ${ }^{3}$.

\footnotetext{
${ }^{2}$ The Groningen data does not include records from the city of Groningen, but it is complete for the rest of the province.

${ }^{3}$ There is mixed evidence that the marital status of the mother affects her risk of maternal mortality. One Swedish study found single mothers to have a significantly higher risk of death (Andersson et al.,
} 
Risk factors of maternal mortality in the Netherlands during the nineteenth century which are available for study include both social factors such as social class, regional, year and seasonal effects, and biological factors including maternal age, birth spacing, and reproductive history. Many important medical, biological, and social risk factors are not available in the data, such as workforce participation of pregnant women, nutrition, lack of hygiene among doctors and mothers, sophistication of medical techniques, and access to medical care. These factors cannot be included in the quantitative analysis but the extent to which they were applicable to mothers in the Netherlands during the $19^{\text {th }}$ century will be explored.

This study will build on previous research by first discussing what is currently known about trends and risk factors of maternal mortality in the Netherlands and how this compares to other countries. There is much to be gained from a study of the Netherlands. To begin with, very little is known about Dutch maternal mortality prior to the late nineteenth century. What we do know is that the Dutch case is unique among European countries with regard to the quality and method of midwife certification and training standards, and because hospital births were not very common (M.J. Van Lieburg \& Marland, 1989), a trend which persisted well into the 1960s (Van Daalen, 1993). Other sources suggest that maternal mortality likely fell rapidly after 1851 in the Netherlands (Shepherd et al., 2011). By the last quarter of the nineteenth century, when standardized cause-of-death records are available, the maternal mortality rate in the Netherlands was among the lowest in Europe (I. Loudon, 1992) (see Figure 1). In order to know how that

2000) while another found no relation (Hogberg \& Brostrom, 1985). On one hand, unmarried women were more likely to deliver in hospitals where the risk of contracting puerperal sepsis, a major cause of maternal mortality, was higher (Van der Waals, 1987). On the other hand, the fertility rate of unmarried women was quite low. Only $1.21 \%$ of unmarried women between ages 15-49 gave birth at the beginning of our study in 1846 . By 1902 this number had halved to $.63 \%$, or approximately $2.5 \%$ of all births (CBS, 1975). 
happened, we look to the preceding decades for clues.

Figure 1 about here

Following the historical overview is a more detailed discussion of the family reconstitution data and methods used to determine the odds of maternal mortality from various risk factors. The data cover three of 11 Dutch provinces in the nineteenth century. Finally, the trends and determinants of maternal mortality from 1846 to 1902 in the Netherlands will be revealed and implications for theory assessed.

\section{Background}

Knowledge of Dutch maternal mortality prior to the late nineteenth century comes from very few and mostly very local sources. Evers (1864) compared maternal mortality in the city of The Hague in the period 1756-77 with that of the years 1856-62. Data were deduced from the local system of death registration, compiled on the basis of the deaths reported to the town clerk's office. Evers concluded that maternal mortality had decreased from 13.6 per 1000 births to 5.0 , a tendency which 'for sure could be credited to the progress of obstetric science'. Several obstetricians published data on the results of their long-lasting local practice in the last decades of the nineteenth century (Beekenkamp, 1909; Duyzings, 1951; Persant Snoep, 1853; Prillevitz, 1909; Smulders, 1962). A family reconstitution study of eighteenth century Maasland, South Holland, estimates that roughly 13.9 women died in childbirth per 1000 births (Noordam, 1986). In Friesland around the same time, notes from midwife Catharina Schrader's journal report that she delivered roughly 3000 to 4000 newborns during the course of her career, with 20 total maternal fatalities, or 5.7 deaths per 1000 births (M.J. van Lieburg \& Kloosterman, 1987). Schrader's leading cause of death was puerperal fever, followed by haemorrhage, thrombosis 
(blood clot), and eclampsia (convulsions associated with high blood pressure) (M.J. van Lieburg \& Kloosterman, 1987). Finally, a journal of another Friesian, the man-midwife and general practitioner Jelle Banga, reveals that a century later Banga delivered over 1000 babies and reported 38 cases of maternal mortality, one of whom was his own daughter (M.J. van Lieburg, 1991). Cobbling together these studies lends some idea of maternal mortality prior to official statistics, but the picture remains incomplete without a systematic study of more regions and more reliable data. The records of Schrader's (I. Loudon, 1992) and Banga's (M.J. van Lieburg, 1991) practice are likely not representative of the average maternal mortality rate. Starting with the beginning of the twentieth century, however, more detailed information is available. In her famous 1911 study, Van Tussenbroek compiled maternal death records from Dutch hospitals, cities, and provinces to reveal a declining maternal mortality rate due to puerperal fever in the late nineteenth century. Another study of a sample of registers in three provinces and one city (Rotterdam) in the Netherlands mixed with national data when available confirms this decrease. According to the study, maternal deaths per 10,000 births fell from 124.7 in 1851 to 25.6 in 1915 (Shepherd et al., 2011, 246).

\section{Medical Risk Factors}

These sources suggest that maternal mortality was decreasing over time. Maternal mortality is the result of several possible complications of birth. In order for the maternal mortality rate to decrease, that means that at least one of these complications was either less commonly observed or the probability that it resulted in death decreased during our period of observation. Our data do not allow for a break down of maternal mortality by cause of death. However, we can to some extent deduce cause of death from timing of death and this can be corroborated with the historical records that are available. 
Dutch cause of death statistics in the form of standardized records recorded by doctors were first required on a national scale in 1865 . By 1875 maternal death had been divided into puerperal fever and other accidents of childbirth (Neurdenburg, 1925). This classification system reveals the importance of puerperal infection in the late nineteenth century. Beginning in 1875 puerperal fever was responsible for 19 maternal deaths per 10,000 births in the Netherlands. Five years later, around which time anti- and asepsis practices were becoming widespread (Shorter, 1982), the national maternal mortality rate due to puerperal fever had decreased to just five per 10,000 births (F. Van Poppel \& Ekamper, 2010). Another source corroborates this drop and estimates it at $8.7 \%$ for all maternal mortalities (Van Tussenbroek, 1911). In a population of roughly 2.9 million women in the childbearing years, these changes in the national rates are statistically significant. Puerperal fever was not just a common cause of death in the Netherlands, but plagued pregnancies internationally.

In addition to infection, the ICD-10 acknowledges eight other groups of obstetric causes of death, including abortion (medical or spontaneous), hypertension, hemorrhage, obstetric complications, non-obstetric direct deaths (e.g. suicide), unanticipated complications of management (e.g. complications caused by anesthesia), non-obstetric complications (e.g. exacerbation of pre-existing conditions), unknown/undetermined cause of death, and coincidental causes (e.g. assault) (World Health Organization, 2012). The causes of maternal mortality in the $19^{\text {th }}$ century in the Netherlands would have been much the same as they are today; only the frequency of observed causes would vary. In particular, obstetric complications including obstructed labor, malpresentation of the fetus, and a small pelvis due to rickets or childhood malnutrition would have been more common causes of maternal mortality. Hemorrhage was another major cause of death. Placenta previa, where the placenta is delivered 
before the fetus, was not very common, but was well-known because it was greatly feared (Shorter, 1982). Hemorrhage more often occurred because the uterus would not stop contracting after labor, resulting in blood loss leading to death. Eclampsia and thrombosis were also causes of death that midwifes and doctors would have seen at the time. Abortion was likely not common, at least until the very end of our period of observation. This is because techniques were mostly ineffective until the end of the $19^{\text {th }}$ century and a high infant and child mortality rate would have made limiting fertility redundant (de Bruijn, 1979). 80\% of maternal mortalities occurred within two weeks of delivery (Loudon, 1992). In the provinces of Limburg (Starmans, 1930) and Overijssel (Hagenbeek, 1936), the first week and a half after delivery were considered critical. In particular it was thought that the ninth day was dangerous, and women would go back to bed on that day even if they had a healthy pregnancy and had already been performing light housework before then. The importance of the ninth day may be related to the incubation period of puerperal sepsis, which if not present by then would probably not present itself.

Obstetrics as a science developed considerably at the end of the $19^{\text {th }}$ century, possibly contributing to the decline in maternal mortality. Caesarean section and other extraction techniques became safer during this time, though caesarean section was still rarely employed. These improved techniques would have presented another option for dealing with obstetric complications, possibly preventing death from such causes (Van der Waals, 1987).

Furthermore, infection responsible for puerperal sepsis got worse before it got better in the late $19^{\text {th }}$ century. Semmelweis discovered how puerperal sepsis spread in 1846 , but his ideas were ignored by many, including the then director of the Amsterdam hospital, Lehmann. Combined with a hands-on teaching policy for doctors in training, this ignorance contributed to 
one of the worst outbreaks of puerperal fever in the Netherlands. It got so bad that the clinic shut down for a few months in 1880. Upon its reopening, van der Mey, a doctor who accepted Semmelweis' theory on hygiene, took over direction of the clinic and puerperal fever rates decreased (Van der Waals, 1987; Verdoorn, 1965). In Leiden findings regarding hygiene were accepted by Halbertsma, who avoided a death toll as high as the one in Amsterdam by only allowing external examination of women in labor (Van der Waals, 1987).

\section{Biological Risk Factors}

In addition to medical advances, changes in distribution of characteristics of women giving birth may have also improved or exacerbated the risk of maternal death. These characteristics include birth interval, parity, maternal age, and outcome of previous pregnancy.

Short birth intervals of six months between termination of previous pregnancy and conception (Conde-Agudelo \& Belizan, 2000) and 24 months from pregnancy to pregnancy (Anandalakshmy, Talwar, Buckshee, \& Hingorani, 1993) have been associated with an increased risk of maternal mortality. This is thought to be explained by exhaustion and depleted nutrients on behalf of the mother. Long intervals prior to reliable birth control would indicate problems in conceiving, which might also lead to problems in child birth. An interval of 75 months or more was shown to be a significant indicator of maternal death in a study of modern Bangladesh (DaVanzo et al., 2004).

A woman's ability to recover energy between pregnancies may likewise be hampered by high parity. This could also contribute to hemorrhage (Lepoeter \& Teeuw, 2010). Parity over five and eight, respectively, have shown to be significant risk factors (Andersson et al., 2000; 
DaVanzo et al., 2004), though not conclusively (Högberg \& Wall, 1986). On the other hand, primiparity has also been shown to affect maternal mortality (Andersson et al., 2000).

Late maternal age has also been associated with increased risk of maternal death in both historical and contemporary studies (DaVanzo et al., 2004; Högberg \& Wall, 1986; Ronsmans \& Campbell, 1998). One study found that age as a risk factor became more strongly associated with maternal mortality as the tendency toward pregnancy after age 35 decreased once it was possible to limit fertility (Högberg \& Wall, 1986). This is thought to be due to a selection effect, whereby the group left having children at risky ages may be socioeconomically disadvantaged (Högberg \& Wall, 1986). In addition to the potentially dangerous effects of bearing children at a late age as described earlier, it is also thought that maternal mortality may be more common for extremely young pregnancies. The J-shaped effect of age where pregnancies at the beginning and end of the fertility period are associated with increased mortality risk was found in Matlab, Bangladesh (Ronsmans \& Campbell, 1998) and Sweden (Högberg \& Wall, 1986). Furthermore, there may be some additional complications when age and parity are considered together. First parity at any age is dangerous, but unusually high or unusually low parity for an age group may also be dangerous (Ronsmans \& Campbell, 1998).

A woman's ability to recover energy between pregnancies may also be hampered by an exceptionally demanding index or prior pregnancy as caused by a stillbirth (Andersson et al., 2000; Ronsmans \& Campbell, 1998) or multiple gestation (Conde-Agudelo, Belizan, \& Lindmark, 2000).

\section{Sociological Risk Factors}


In addition to biological risk factors, factors of a woman's environment could influence her risk of maternal mortality, including social class, region, year, and the season of giving birth.

To the extent that social class affects women's labor force participation, it could also affect pregnancy outcomes. Strenuous physical activity during the last trimester of the pregnancy, such as what might have been performed by farmers' wives in the harvest months, has been associated with riskier pregnancies, including preterm delivery (Ramirez, Grimes, Annegers, Davis, \& Slater, 1990). Although we expect that maternal mortality would, like infant mortality (Ward, 2003), disproportionately affect the lowest social classes, other historical studies into maternal mortality have found that belonging to the elite social class may be dangerous in some situations (Irvine Loudon, 1986). Loudon finds excess elite maternal mortality in England and Wales in the late $19^{\text {th }}$ and early 20th centuries, and posits that this is because the supposedly superior medical care elite women received during their delivery actually increased the risk of maternal mortality. Doctors might have been more anxious to operate than midwives, or more empowered to do so, thus risking the spread of puerperal sepsis (Irvine Loudon, 1986).

On a global scale, there were a few events in the nineteenth century which affected overall mortality directly and may have directly or indirectly affected maternal mortality. Cholera epidemics in 1849 and 1866 and a smallpox outbreak in 1871 may or may not have resulted in true maternal mortalities, but most likely did contribute to the number of pregnancy related deaths as they are defined in this study (See Figure 3). Furthermore, nutrition levels for the lower classes in the first half of the nineteenth century were probably just at or under the minimum caloric intake necessary to be considered adequately nourished (Wintle, 2000). As a result, food shortages would have had an immediate and noticeable effect. The penultimate 
famine in the Netherlands (the last being the Hunger Winter in 1944-45) occurred with the potato blight in the late 1840s, after which food consumption gradually rose to healthier levels by the beginning of the twentieth century (Wintle, 2000).

Annual and seasonal variation in food availability may likewise affect maternal mortality via nutrition. In eighteenth and nineteenth century rural Germany, female mortality relative to male mortality was higher in the winter than the summer, possibly due to the way food was allocated in households with a larger portion going to the men than the women (Klasen, 1998). If this seasonal effect holds true in the Netherlands, decreased access to food during a famine or in winter might increase the risk of maternal mortality. On the other hand, seasonal variation also dictates the type of work women would be engaged in, particularly for farmers' wives. The labor-intensive months of the harvest might be particularly dangerous for pregnant women in their last trimester.

The region in which women lived may have affected their risk of maternal mortality for a number of reasons, some of which are outlined below.

\section{Study Area}

This study covers the three provinces, Zeeland, Drenthe, and Groningen, for which family reconstitution data is available. At the time, the Netherlands consisted of 11 provinces. Although not strictly a random sample, these provinces are diverse with regard to representing both costal (Zeeland and part of Groningnen) and inland (part of Groningen, Drenthe) as well as northern (Groningen and Drenthe) and southwestern (Zeeland) provinces. These distinctions are important socially and economically, with fertility, employment, resource, and mortality patterns differing across these provinces. Their diversity lends support to the empirical basis of this study. 


\section{Fertility}

At 5.09 births per marriage, Zeeland had the highest average fertility rate of the three provinces while Drenthe had the lowest with just under four births per marriage. This could in part be due to the lower incidence of breastfeeding in Zeeland compared to Groningen and Drenthe (Treffers, 2009), which in turn resulted in shorter birth-to-birth intervals. Perhaps not surprisingly, shorter birth intervals and a lesser inclination to breastfeed went hand in hand with higher infant mortality rates in Zeeland as compared to the other two provinces. $15.93 \%$ of all infants born in Zeeland from 1846 to 1902 died compared with $10.29 \%$ and $11.82 \%$ respectively in Drenthe and Groningen (Figure 2, Table 1).

Figure 2 about here

Table 1 about here

\section{Employment}

In the census of 1849 , a little more than half of the women aged 16+ in Zeeland were gainfully employed (Table 1). This was quite a lot compared to women in Groningen where $34 \%$ were employed. The high female employment rates in Zeeland may partially explain why breastfeeding was less common there. Aside from any cultural reason not to breastfeed (which likely also existed (Treffers, 2009)), working women may be less able to breastfeed their children, thereby decreasing the length of their natural postpartum amenorrhea which in turn would enable shorter birth intervals. By 1899, Zeeland still reported the highest employment rate among women ages $16-50$ of any province, but rates all over the country were much lower. This drop in female employment coincides with the emergence of the housewife norm whereby married women gradually ceased to work outside of the home over the course of the nineteenth century (F. Van Poppel, Van Dalen, \& Walhout, 2009). 


\section{Resources}

By 1899 , Groningen and Drenthe both had roughly one midwife per 1250 women between ages 16 and 50, while Zeeland had the highest ratio with only one midwife per 1572 women (see Table 1). In terms of water supply, drinking water for Zeelanders and residents of coastal areas in Groningen was probably frequently salty, bordering on undrinkable at times, and may have contributed to the prevalence of malaria and communicable diseases (Hofstee, 1978). The water in the inland area of Groningen and Drenthe would have been more potable. Pregnant women in general have a weakened immunological response, therefore they would have been particularly susceptible to death as a result of malaria and other diseases (Hogberg \& Brostrom, 1985; Schofield, 1986). With regard to nutrition, inhabitants of Zeeland also suffered more long-term consequences of the food shortage in the late 1840s than did people living in Drenthe or Groningen, as evidenced by average height of army conscripts born in years of famine (Paping \& Tassenaar, 2007). To the extent that infants' growth was stunted in utero, lack of food would have also affected the mother, possibly contributing to increased maternal mortality.

\section{Mortality}

Drenthe women died the youngest, on average, of all three provinces. Furthermore, women aged 25-50 in Drenthe had a 20\% higher chance of mortality than men. By comparison, this relationship was reversed in North and South Holland (F. Van Poppel, 2004). Furthermore, diseases such as malaria and diseases of the digestive tract have also been linked to maternal mortality (Hogberg \& Brostrom, 1985). This is particularly relevant for Zeeland and Groningen, as the larvae which carry malaria thrived in the brackish water in these regions during the nineteenth century (Hofstee, 1978). Finally, a comparison of maternal mortality across Dutch 
provinces in the last quarter of the nineteenth century reveals that Drenthe, at $7.1 \%$ maternal mortality per birth, had a higher maternal mortality rate than either Groningen (5.8\%) or Zeeland (5.3\%) (Van Tussenbroek, 1911).

\section{Other provinces}

Despite the range presented in this data, there are some gaps due to lack of information about other provinces. In particular, the provinces in our data are all provinces where there are relatively few Catholic women. The high rate of Catholicism in North Brabant and Limburg, among other provinces, would have affected fertility norms. Religious ideology would have valued high parity, and women in these regions would have on average higher parity and shorter birth-to-birth intervals than the provinces in our study. Furthermore, a movement on behalf of the Catholic Church discouraged women from breastfeeding because it was thought to be indecent (Kok \& Van Bavel, 2006; F. W. A. Van Poppel, 1985). Low incidence of breast feeding would have contributed to shorter birth intervals because post partum amenorrhea generally only lasts as long as a woman lactates.

\section{Data}

This family reconstitution study uses linked birth, marriage, and death certificates from three Dutch provinces, Drenthe, Groningen, and Zeeland, covering the Netherlands during the nineteenth century. Vital records for each of these provinces were standardized and linked based on first and last names, dates, and location information provided on the records. Because death records were available from 1812 to the 1950s but birth records were only available from 1811 to 1902, the time period for this project ends on February 11, 1903 (42 days after the last birth record). The time period begins in 1846 because this is the year that women born in 1796 (A) 
and entering their reproductive periods at the beginning of observation in 1812 (B) would be leaving the fertile period (i.e., turning 50, (C)). By beginning analysis in 1846, we can start the analysis at a point when women at all stages in the reproductive cycle are available for observation. That is, 1846 is the first date which includes complete reproductive history for all women aged 16 to 50 (See Figure 3).

Figure 3 about here

All births and deaths in Drenthe, Zeeland, and Groningen ${ }^{4}$ are recorded in the LINKS database, thus allowing us to know rather than estimate the maternal mortality in these provinces. Having a dataset that covers all births during a given time period is valuable for studies of maternal death because maternal mortality is a rare event, and its infrequency makes it difficult to find significant effects. Nonetheless, maternal mortality rates have to be interpreted with caution because random variation from one year to the next can make a trend appear where there is none. For example, a true mortality rate of 50 deaths per 10,000 births in a population with 10,000 annual births can disguise itself as a maternal mortality rate ranging from 35 deaths per 10,000 births to 65 deaths per 10,000 births simply through random variation (Loudon, 1993). The number of births per year in this study ranges from 8,229 in 1847 to 15,740 in 1901 . Likewise, the $95 \%$ confidence intervals range from +/- 21.04 in 1847 to +/- 9.96 in 1901 .

Even when we know the $95 \%$ confidence interval for a given year, it is not always possible to know whether the historical records themselves are complete. According to law after 1812, the government required that all births, deaths, and marriages be recorded in a uniform way throughout the Netherlands. Nonetheless, mistakes were probably made both in the initial

\footnotetext{
${ }^{4}$ Except for Groningen city
} 
failure to (accurately) record births, marriages, and deaths and in the present-day attempt to link these records. Furthermore, the entire reproductive history of all families with implausible or contradictory birth and death records (e.g. mother's death predating child's birth, mother younger than 15 or older than 50 ) were excluded from analysis, as were cases where the child's birth date or the mother's age were missing and impossible to estimate. 38 cases $(0.03 \%)$ were deleted because the child's birthday was missing. Mother's birth date was missing for 2,574 cases $(0.2 \%)$.

The resulting data for analysis has information on 176,054 families and 740,995 births. In Groningen, there were 260,112 births during the period of observation and 1,804 maternal deaths, Zeeland had 311,306 births and 2,231 deaths, and Drenthe had 169,577 births and 1,330 deaths. (See Table 1 for key figures distinguishing provinces). The average woman gave birth 4.49 times, was 31.44 years old at the time of her child's birth, and was married to an unskilled worker. Because the records are linked by marriage, there are no observations of children born out of wedlock. However, the database does include stillbirth data on 32,156 cases of both true fetal deaths and live born infants who died before their birth certificate was issued. 10,622 births, or roughly $1.4 \%$ of all births were to twins or multiples. Although these births differ quite a bit from singleton births, it was decided to leave them in for comparability with other studies which are not able to distinguish between multiple and singleton births. Nonetheless, all analysis was performed on data with and without multiple gestations included and yielded the same results. 5,365 mothers died in childbirth or within 42 days of delivery between 1846 and 1902 . Half of the women who died did so on or before day eight. In most cases it was not possible to distinguish mothers who died prior to approximately seven months into their pregnancy, as the child would likely not have a death certificate in its name. In 1869 a law was established that 
required a burial permit and accompanying death certificate for all stillborn children born after seven months gestation, however the registrar could not refuse a burial permit for a child with less than seven months gestation (Van Poppel, 2003).

\section{Dependent variable}

The International Classification of Diseases (ICD) defines a maternal death as the death of a woman while pregnant or within 42 days of termination of pregnancy, irrespective of the duration and site of the pregnancy, from any cause related to or aggravated by the pregnancy or its management but not from accidental or incidental causes while a pregnancy-related death is the death of a woman while pregnant or within 42 days of termination of pregnancy, irrespective of the cause of death. (World Health Organization, 2004). Maternal mortality in this study actually refers to pregnancy-related maternal death. Although the later definition undoubtedly captures non-maternal deaths, it has been shown to mirror maternal mortality trends based on cause of death data for an historical population (Andersson et al., 2000). Furthermore, this method is often used as an approximation of true maternal mortality (Hammel \& Gullickson, 2004; Hogberg \& Brostrom, 1985). It is difficult to know exactly how many non-maternal deaths would have been misclassified as maternal deaths, but maternal deaths according to official statistics from 1875-1902 account for on average 60\% of the family reconstitution figures (see Figure 4).

Figure 4 about here

Even though the "true" maternal mortality rate for any given time period is probably not as high as a study based on family reconstitution would suggest, the rate is likewise probably not as low as official statistics report. Official statistics might have been underestimated for many reasons. 
First, the doctor issuing the birth certificate could simply have made a mistake and, for example, not associated a death with a recent pregnancy (Loudon, 1993). Second, the doctor could have intentionally hid the cause of death in an attempt to escape culpability. Evidence from England and Wales suggests that this certainly did occur, especially after attention was brought to the high maternal mortality rates in the late nineteenth and early twentieth century. Doctors would hide a maternal mortality by listing cause of death as "peritonitis" or "septicaemia" instead of puerperal fever (Loudon, 1993), a technically accurate but misleading description. Although these first two situations likely did occur, evidence suggests that they probably did not greatly impact maternal mortality rates (Loudon, 1993). A much more common way in which pregnancy could have been overlooked as cause of death occurred with a pregnant woman dying of a disease such as tuberculosis or malaria which was exacerbated by the pregnancy. Although pregnancy would probably not have been listed on the death certificate, had she not been pregnant, she would not have died. This continues to be a problem with official maternal mortality statistics (Bouvier-Colle, Varnoux, Costes, \& Hatton, 1991).

An important advantage of this dataset is that it records stillbirths. This is useful because stillbirths were closely linked to maternal mortality, and many maternal mortalities may be miscategorized in a family reconstitution study if it were not possible to link the death of the mother to that of the child. By comparison, countries that did not record stillbirths, such as England and Wales (Schofield, 1986), likely underestimate the true maternal mortality rate.

At the same time, there are possibly maternal deaths which occurred after 42 days postpartum. The ICD definition is commonly accepted, but there is some question as to whether the 42-day cutoff sufficiently captures maternal mortality as it was established for historical 
rather than medical reasons (Hoj, Da Silva, Hedegaard, Sandstrom, \& Aaby, 2003). English and Swedish studies adhere to 42 days postpartum but other studies have used 30, 60, or 90 days, 6 months, or one year (Bouvier-Colle et al., 1991; Schofield, 1986). For ease of comparison with other studies and because this is the official ICD definition, the dependent variable in this study is pregnancy-related death within 42 days of termination of pregnancy. When comparing deaths within 42 days to deaths within one year of pregnancy in this study, it appears that more than half $(53.25 \%)$ of all mortalities within a year of giving birth occur within the first 42 days. This is in keeping with another study that found that $59 \%$ of all maternal deaths had occurred within 42 days (Andersson et al., 2000). The bigger the time frame, the more likely indirect deaths will be counted along with direct maternal mortalities.

\section{Covariates}

Several intermediate and distant risk factors of maternal mortality will be explored in this section. Maternal age at birth, birth spacing, and reproductive history (parity, twins or multiples, stillbirths) are some of the most commonly studied and influential intermediate risk factors of maternal mortality. Another less-studied but potentially important intermediate risk factor is season of birth. Distant determinants included in this study are social class, year, and province. Some summary statistics of the variables used in this study are provided in Table 2.

Table 2 about here 


\section{Biological risk factors}

Maternal age. Because maternal age is thought to be $\mathrm{J}$-shaped with young and old pregnancies posing the highest risk of complications, age will be included as a linear and squared term in order to test the non-linear relationship between age and maternal mortality.

Birth spacing. Birth interval is treated as a categorical variable, with groups of 252-730 days (824 months), 731-2283 days (24-75 months), 2283 days or more while birth interval for parity 1 is not included. Although birth intervals existed in the dataset which were shorter than 252 days, it is likely that some of these intervals were incorrectly recorded. The entire birth histories of women with unrealistic recorded birth intervals were removed from analysis. The cutoff time period of 252 days was chosen because it is the estimated length of conception for stillbirths (Ronsmans \& Campbell, 1998).

Parity. For the purposes of this study, parity is measured in categories: parity one, parity twoseven, and parity eight and higher. Grandparity was defined as parity eight and higher in keeping with a study in Bangladesh (DaVanzo et al., 2004) rather than as four and higher as it was done in Sweden (Högberg \& Wall, 1986) because the average woman gave birth to between four and five children.

Age and parity interaction. Parity as a categorical variable is interacted with age as a continuous variable to determine overall risk of parity at a given age.

Stillbirth and multiple gestation. Dummy variables measuring such births in both the index and prior pregnancy are included. 


\section{Sociological determinants}

Season. Season in which child is born is included as a categorical variable with winter being the index. Pregnancies occurring in December-February are coded as a winter birth, March-May is spring, June-August is summer, and September-November is fall.

Social class. Social class in this study is determined based on the father's occupation on birth, death, and marriage certificates. This occupation was coded into internationally comparable HISCO occupations and then classified using the Social Power (SOCPO)-social class scheme of van de Putte \& Miles (2005). The SOCPO classification scheme organizes occupations into five categories where level 1 represents the lowest, unskilled jobs and level 5 represents the elite. Middle class (level 4) was further divided into farmers and non-farming middle class. Additionally, a category for unknown was added because many occupations were not listed on vital records.

Province. Province is a dummy variable with Drenthe as the reference category.

Year of giving birth. Year in which mother gave birth is measured by dummy variables, with year being broken down into decades from 1846-1895, and one 7-year period from 1896-1902. This is a control for changes over time with regard to average economic standing.

\section{Method}

Three Poisson models were used to estimate the risk of maternal death within 42 days of termination of pregnancy, given the variables described above. If a woman gave birth multiple 
times, she is represented multiple times in the data. Poisson and Cox models were originally compared, but the Poisson model was chosen because it fits both the concept and data better $\left(\mathrm{AIC}_{\mathrm{cox}}=141,991.17 ; \mathrm{AIC}_{\text {poisson }}=61,032.54\right)$. Conceptually we are not interested in time until maternal mortality per se, but in the frequency with which maternal mortality occurs. In practice, however, these models yield similar results. Only the strength of the risk factors differs depending on the method of analysis; the significance and direction of all covariates are the same in both models. We account for multiple births by the same mothers by using time-varying variables whose values are adjusted for each birth, such as age, parity, and characteristics of the previous birth. This method has been used in previous studies and is thought not to deflate standard errors (c.f. Hammel \& Gullickson, 2004).

\section{Preliminary results}

\section{Trends}

The maternal mortality rate as defined by the number of maternal deaths per 10,000 births in Groningen, Drenthe, and Zeeland decreased steadily from 1846 to 1902 (Figure 5). Maternal mortality rate fluctuated more dramatically during the beginning of the period of observation due in part to smaller overall numbers of births and evened out as the number of births increased throughout the 1800 s. A few peaks in the maternal mortality rate correspond with cholera and smallpox epidemics (Figure 5), indicating that either non-maternal deaths were captured in the maternal mortality figures due to the attribution of all deaths within a few weeks of delivery to pregnancy, or that women were more susceptible to death from these diseases or causes during and after pregnancy. However, this food shortage does not directly correspond to a peak in the 
maternal mortality rate. Rather, the increase in maternal mortality which followed in 1848 points to a lagged effect of the potato famine of 1847 . The cholera epidemic in 1849 also increased maternal mortality.

Figure 5 about here

Figure 4 shown earlier illustrates how the data based on family reconstitution data compares to national cause-of-death statistics available after 1875 and to province-specific rates. Figure 6 reveals that each region followed the national downward trend. In general, there was little variation between regions in maternal mortality, and many apparent differences between provinces can be explained by random fluctuation. Nonetheless, some variation between provinces persists. Drenthe began with the lowest maternal mortality rate and ended with the highest rate while Zeeland began with the highest rate and ended with the lowest. This difference between provinces echoes the infant mortality rate, which dropped dramatically in Zeeland in the nineteenth century but stayed relatively constant in Drenthe (Vandenbroeke, Van Poppel, \& Van der Woude, 1984). In the case of maternal mortality, it is the relatively slow rate of decrease in Drenthe which needs to be explained because maternal mortality rates in Zeeland and Groningen behaved most similarly to the three province average. Drenthe's slow and late decrease in the maternal mortality rate could be due in part to the fewer number of births per mother compared to women in Zeeland and Groningen. Our data suggest that a mother's first birth was her most dangerous one. As a result, the maternal mortality rate would appear to be higher in a population where parity 1 makes up a larger proportion of all births. Furthermore, the trend over time was toward fewer births per mother. As the nineteenth century progressed, Drenthe women would have given birth to even fewer children, thereby increasing the frequency of maternal death per 
10,000 births. It should also be noted that the apparent dramatic drop in maternal mortality in Zeeland may be due in part to exceptionally high maternal mortality at the beginning of the study. That is, initial maternal mortality rates were higher than average, but the subsequent decrease was on par with what was happening in other provinces. The initial spike in maternal mortality in Zeeland could be explained by the fact that Zeeland was struck particularly hard by the potato famine which coincided with the beginning of this study (Paping \& Tassenaar, 2007).

Figure 6 about here

\section{Univariate analysis}

Before beginning with the statistical modeling, we first present some univariate statistics that reveal the association between certain risk factors and maternal mortality. Table 3 illustrates the frequency (proportion) of the biological risk factors among healthy births and among those that result in maternal mortality. As can be seen, high parity, advanced age, a stillbirth in the index and prior pregnancy, and multiple gestation in the index pregnancy are all associated with a maternal mortality rate that is higher than what would be expected by chance alone. The prevalence of all biological risk factors is significantly different among births with a maternal mortality and those without.

Table 3 about here

The group comparison is repeated with social risk factors in table 4, revealing that farmers, women giving birth prior to 1876 , women giving birth in the winter, and women in Drenthe have a disproportionately higher rate of maternal mortality. On the other hand, other middle class individuals, women giving birth after 1886, women giving birth in the spring or summer, and women in Groningen have a disproportionately low rate of maternal death.

Table 4 about here 
As no information is available on the cause of death, a closer examination of the timing of death and certain risk factors in relation to childbirth can reveal clues about the frequency of certain causes. Perhaps shedding light on the superstition regarding the ninth day after delivery, it seems a little more than $70 \%$ of maternal mortalities occur within the first two weeks (see table 5). The $30 \%$ of deaths occurring after two weeks are likely due to infection or comorbidity with other diseases (malaria, tuberculosis, etc.). Deaths due to hemorrhage, thrombosis, eclampsia, or obstetric complications would likely happen much sooner, though horror stories exist of such causes of death dragging out for days and even weeks. One women in Zeeland died from blood loss 21 days after delivery, for example (Lepoeter \& Teeuw, 2010). High parity births were more likely to result in maternal mortality in the first 24 hours of delivery than were low parity births (Table 6).

Table 5 about here

Table 6 about here

In table 3 we have seen that stillbirth is highly associated with maternal mortality. We expect that stillbirths were consistently associated with maternal mortality by obstructed labor. This association would have persisted throughout our study, decreasing only when caesarean sections became safer and more common. Indeed, table 7 reveals that the percentage of stillbirths which ended in a maternal death did not vary greatly from 1846 to 1902.

Table 7 about here

Although the incidence of death associated with stillbirths was not changing over time, a greater proportion of deaths occurred within the first day of the postpartum period (see table 8) even while the total proportions of births that ended in deaths was decreasing. This is perhaps because, as the incidence of puerperal sepsis decreased, the more important risk factors became those 
which killed within the first hours of delivery: hemorrhage, eclampsia, thrombosis, and other obstetric complications. Similar to the observation that deaths associated with stillbirths were constant over time, this could be because deaths within the first 24 hours were due to factors endogenous to the birth and while puerperal sepsis was preventable, the endogenous factors were not. A similar trend was observed for infant and child mortality whereby child mortality was more susceptible to class differences than infant mortality (Frans Van Poppel et al., 2005).

Table 8 about here

\section{Risk Factors}

Table 9 shows the results from three analyses, with model 1 being the increase (or decrease) in the incident rate ratio (IRR) of various biological risk factors. Model 2 includes an interaction between parity and age, as well as a test of the non-linear effect of maternal age. Model 3 includes sociological factors

Table 9 about here

A review of the biological risk factors of maternal mortality in Model 1 reveals that giving birth to a stillborn child is by far the greatest indicator of maternal mortality (IRR: 5.75). The chance that a mother will die in childbirth is 5.75 times greater when the fetus dies before delivery. Likewise, giving birth to twins or multiples in the index pregnancy significantly raises the odds of maternal mortality, and parity one and parity eight or greater exhibit a u-shaped influence on the risk of maternal mortality. Although the role of prior pregnancy as a risk factor acts in the expected direction, the effect was not significant for either prior stillbirth or prior multiple gestation. Length of birth interval behaves partially as expected, and significantly increases mortality odds for intervals of less than 24 months (IRR: 1.11), though it has no 
significant effect for intervals greater than 75 months. Both first and late parities represent an increased risk of maternal mortality, with parity 1 increasing risk by 50\%, and parity 8 or higher increasing risk by $10 \%$. Maternal age increases risk of maternal death by $4 \%$ each year. When we add a non-linear term for age and an interaction between parity and age in model 2 , we see that neither are significant and that the model is not significantly improved by these additions. Finally, we add the social risk factors in model 3. In addition to the previously described biological risks, the risk of maternal mortality was $11 \%$ higher for skilled workers and $31 \%$ higher for farmers than it was for the average unskilled worker. Living in Groningen and Zeeland were both significantly safer for pregnant women than living in Drenthe, as was giving birth in the summer or fall. Furthermore, including the decade of delivery reveals a significant trend toward a lowered chance of maternal mortality over time.

\section{Discussion}

\section{Trends}

The findings regarding maternal mortality trends fit nicely into existing knowledge of nineteenth century maternal mortality. Loudon (1992) hypothesized that the maternal mortality rate in Europe in the nineteenth century would have changed dramatically after the 1870 s with the introduction of antisepsis and asepsis into doctors' and midwives' routines. He estimates this drop to be about $40 \%$ in the Netherlands. The family reconstitution data confirm his hypothesis. Indeed, the last seven years of the study (1896-1902) show that a woman giving birth between 1896 and 1902 had roughly a $42 \%$ lower risk of maternal mortality, all else being equal, than a woman giving birth between 1876 and 1885 ( $\mathrm{p}<0.001$; Table 9). The drop in maternal mortality at the end of the century reconfirms other studies reporting similar drops, including the official 
cause of death statistics (see Figure 4) and van Tussenbroek's (1911) study of late nineteenth century maternal mortality.

The downward trend shown in Figure 4 holds true even when comparing maternal mortality rates which are standardized using the direct method (Curtin \& Klein, 1995) to account for the changing age and parity distribution (see Figure 7). From the mid nineteenth century to 1902, women gave birth to increasingly fewer children at a lower average age. Because maternal age at birth and parity are known risk factors for maternal mortality, and because the distribution of births by these factors changed during the nineteenth century, it is useful to compare standardized rates. Birth intervals also changed over the 60 years of this study, but not in any clear trend, thus they were not standardized. In Figure 7, the age- and parity-adjusted maternal mortality trend line can be seen to be slightly above the raw maternal mortality trend line. In other words, raw maternal mortality rates decreased slightly faster than the standardized rates. What the graph shows is that by the end of the nineteenth century, 1.7 fewer mothers died per 10,000 births (3.9\% of the raw maternal mortality rate) as a result of the changing demographic distribution. The rest of the apparent decrease describes the actual chance of dying in childbirth. The fact that these two lines follow each other quite closely would suggest that the combined effects of age and parity changing over time did not greatly affect the observed maternal mortality rate. In fact, this combined effect hides some of the individual influence of age and parity. When the age distribution is held constant but parity is allowed to vary over time, the result is that the shifting trend toward an average younger age at pregnancy helped save lives (Figure 7). 2.23 fewer mothers died per 10,000 births (5.2\%) as a result of the shifting age distribution. However, when the parity distribution is held constant and age is allowed to vary over time, it turns out that the trend toward fewer children had no effect or slightly inflated the 
maternal mortality rate (Figure 7). 0.3 more mothers died per 10,000 births $(0.7 \%)$ as a result of the shifting parity distribution. When demographic shifts in age and parity are combined, the effects cancel each other out somewhat. This finding is corroborated by a comparison of maternal mortality rates in Sweden in the nineteenth and twentieth centuries (Högberg \& Wall, 1986). The shifting parity distribution over $200+$ years acted against the decreasing maternal mortality rate. The changing age distribution had the larger effect in both the Swedish study (Högberg \& Wall, 1986) and this one. It is unclear why a shifting parity distribution would act against the decreasing maternal mortality rate, but it could have to do with the relative risk of parity one compared to grandparity. Although parity eight and higher is a significant risk factor in maternal mortality in this study, parity one poses a higher risk. As the overall parity decreases, the proportion of parity one births increases, thus increasing the risk of maternal mortality.

Figure 7 about here

\section{Risk factors}

The univariate statistics presented above confirm that maternal mortality was decreasing over time, and they suggest that this occurred, at least in part, because of improvements in prevention of the spread of puerperal sepsis. The trend toward a greater proportion of births occurring within the first 24 hours even while overall maternal mortalities were decreasing stands out as evidence that puerperal sepsis was becoming less important as a cause of death.

The Poisson models in Table 9 combined with the univariate statistics reinforce other studies regarding the negative effects of multiple gestation, stillbirths, advanced maternal age, low and high parity, and a short birth interval. With the exception of the negative effect of parity one and no effect of a stillbirth or multiple gestation in the prior pregnancy, all of these findings 
suggest that a woman's ability to safely deliver a child might depend on her energy and nutrient reserves during the pregnancy. The significance of these factors might indicate that mothers have less time to replenish nutrients between births less than two years apart, when they are already over 35 years old, when they have had many children, and when the circumstances of the index birth require a lot of energy. This is called the maternal depletion hypothesis, and should be explored more thoroughly in future research. However, our data also suggest that the danger of maternal depletion is not in the extreme cases of depletion, such as a prior stillbirth or multiple gestation, but rather in the gradual buildup of stress on the body. This might support the prior finding that in extreme cases of nutrient deprivation the fetus would suffer and the mother would be protected while the mother would suffer during periods of mild nutrient deprivation (King, 2003).

Furthermore, we found that farmers and skilled workers are at a higher risk of maternal mortality than unskilled workers. This could be because farmers' wives would perform heavy labor throughout their pregnancies, thus contributing to a higher risk of complications, and as a result, maternal mortality. Likewise, skilled laborers may expect the participation of their wives in the family business. Labor itself is not the only cause of mortality, however. If that was the case, one would also expect an increase in mortality when the last trimester took place in the summer or fall when crops would be harvested. On the contrary, we found that giving birth during these seasons is safer than giving birth in the winter or spring. This finding could relate to chances of catching disease which would complicate the pregnancy, or perhaps nutritional levels which would be healthier in the summer and fall than in the winter and spring. The relationship between these two findings should be explored in future research. 
Studying childbirth in the Netherlands during the nineteenth century tells two stories: that of the role of women in society and the intersection of class and gender. Childbirth at this time was dangerous for many, uncontrollable reasons. It was dangerous due to risk of bacterial infection, incomplete knowledge of obstetrics, disease, and food scarcities. However, the question is whether or not it was more dangerous than necessary because of the lower position of women in society or whether some women were more at risk because of the social class to which they belonged. In some places during the nineteenth century, women may not have gotten all the medical attention they needed. It was not unusual at the time to die without being attended by a doctor; roughly 5.7\% of the Dutch population did so in 1875 (Rutten, 1985). However, this rate might have been higher for women than men. A Dutch story from 1839 describes how a farmer suffered more when his cow died than when his wife died; buying a new animal cost money but finding a new wife was free (and potentially even profitable) (Hildebrand, 1839, 400). Folktales from Germany (Klasen, 1998) of a similar time period likewise suggest that farmers were less likely to call a doctor to help their wives than they were to seek medical help for their livestock. On the other hand, one piece of evidence that points towards a relatively high position of women in the Netherlands compared with other countries is the constantly decreasing rate of maternal mortality even after adjusting for the shifting age and parity distribution. While the English had more or less a constant maternal mortality rate from 1850 to 1930 (Irvine Loudon, 1986), the Dutch experienced a decreasing rate.

Furthermore, the association between class and maternal mortality needs to be more thoroughly studied. The wives of farmers had a greater risk of mortality than unskilled workers, but the cause is still unclear. Loudon (1986) found that the elite had a higher rate of maternal mortality in England and Wales from the late 1800s to the 1930s whereas Perrenoud (1981) 
observed the same phenomenon in Geneva among couples marrying in the early nineteenth century, yet this relationship was not found in the Netherlands. Loudon hypothesizes that the higher maternal mortality rates of elite women is due to the invasive approach of doctors compared to midwives. There is some evidence that there was a similar division in the Netherlands between doctors and midwives in obstetric practice. In 1911, van Tussenbroek noted that the maternal mortality rate of women attended by midwives was lower than that of women attended by doctors, though she cautioned against interpreting this as meaning that midwives were safer than doctors. After all, doctors were usually only called when the pregnancy was proceeding abnormally. It could be that elite women in England were attended more frequently by doctors while midwives remained the norm in the Netherlands. Another possible explanation is related to the birth location. Shepherd and colleagues (Shepherd et al., 2011) compare maternal mortality in home deliveries to that of maternity hospitals, and conclude that home deliveries by both doctors and midwives were much safer than hospital deliveries because there was less risk of disease contagion. However, this study was of a later period (1850-1900) and the authors do not measure social class, therefore we do not know if higher levels of mortality in hospitals are related to social class. Nontheless, we know that women in the Netherlands maintained a preference for home births well into the $20^{\text {th }}$ century, thus possibly explaining why there is no observable difference between the elite and unskilled workers.

\section{References}

Anandalakshmy, P. N., Talwar, P. P., Buckshee, K., \& Hingorani, V. (1993). Demographic, socio-economic and medical factors affecting maternal mortality-an Indian experience. Journal of Family Welfare, 39(3), 1-4.

Andersson, T., Bergstrom, S., \& Hogberg, U. (2000). Swedish maternal mortality in the 19th century by different definitions: previous stillbirths but not multiparity risk factor for maternal death. Acta Obstet Gynecol Scand, 79(8), 679-686. 
Antonovsky, A. (1967). Social class, life expectancy and overall mortality. Milbank Memorial Fund Quarterly, 45, 31-76.

Beekenkamp, T. (1909). Verloskundige praxis ten plattelande. Verslag van - en opmerkingen over 1500 partus. Nederlandsch Tijdschrift voor Verloskunde en Gynaecologie, 19, 191-256.

Bouvier-Colle, M., Varnoux, N., Costes, P., \& Hatton, F. (1991). Reasons for the underreporting of maternal mortality in France, as indicated by a survey of all deaths among women of childbearing age. International Journal of Epidemiology, 20(3), 717-721.

De Bruijn, J. (1979) Geschiedenis van de abortus in Nederland: Een analyse van opvattingen en discussies 1600-1979. Amsterdam: Van Gennep.

Conde-Agudelo, A., \& Belizan, J. M. (2000). Maternal morbidity and mortality associated with interpregnancy interval: cross sectional study. Britisch Medical Journal, 321(7271), 1255-1259.

Conde-Agudelo, A., Belizan, J. M., \& Lindmark, G. (2000). Maternal Morbidity and Mortality Associated With Multiple Gestations. Obstetrics \& Gynecology 95(6), 899-904.

Curtin, L. R., \& Klein, R. J. (1995). Direct standardization: Age-adjusted death rates (No. 6): Centers for Disease Control and Prevention / National Center for Health Statistics.

DaVanzo, J., Abdur, R., Rahman, M., Hale, L., Ahmed, K., Khan, M. A., et al. (2004). The effects of birth spacing on infant and child mortality, pregnancy outcomes, and maternal morbidity and mortality in Matlab, Bangladesh: RAND.

Duyzings, A. J. M. (1951). Verloskundige ervaringen van een genees-heel-en verloskundige in de jaren 1852-1900. Nederlands Tijdschrift voor Verloskunde en Gynaecologie, 51, 249-258.

Evers, J. C. G. (1864). De sterfte der kraamvrouwen voor ééne eeuw en thans. Nederlands Tijdschrift voor Geneeskunde, 8, 147.

Hagenbeek, J. H. (1936). Het moederschap in Overijssel. Een onderzoek naar de verloskundige voorziening en de zuigelingenzorg in de provincie Overijssel. Zwolle: Firma H. Tulp.

Hammel, E. A., \& Gullickson, A. (2004). Kinship Structures and Survival: Maternal Mortality on the Croatian-Bosnian Border 1750-1898. Population Studies, 58(2), 145-159.

Hildebrand, H. (1839). De Noordhollandsche boerin. In H. Brown (Ed.), De Nederlanden: Karakterschetsen, kleederdragten, houding en voorkomen van verschillende standen (pp. 399402). 's Gravenhage: Ned. Mij. van Schoone Kunsten.

Hofstee, E. W. (1978). De demografische ontwikkeling van Nederland in de eerste helft van de negentiende eeuw. Een historisch-demografische en sociologische studie. Deventer: Van Loghum Slaterus.

Hogberg, U., \& Brostrom, G. (1985). The demography of maternal mortality: Seven Swedish parishes in the 19th century. International Journal of Gynecology \& Obstetrics, 23, 489-497.

Högberg, U., \& Wall, S. (1986). Age and parity as determinants of maternal mortality--impact of their shifting distribution among parturients in Sweden from 1781 to 1980. Bulletin of the World Health Organization, 64(1), 85-91.

Hoj, L., Da Silva, D., Hedegaard, K., Sandstrom, A., \& Aaby, P. (2003). Maternal mortality: only 42 days? Bjog: An International Journal of Obstetrics and Gynaecology, 110(11), 995-1000.

Khlat, M., \& Guillaume, A. (2006). Les décès liés à la grossesse. Genèse du concept et aspects méthodologiques [Pregnancy-related deaths. Genesis of the concept and methodological aspects]. Rev Epidemiol Sante Publique, 54(6), 543-549.

King, J. C. (2003). The risk of maternal nutritional depletion and poor outcomes increases in early or closely spaced pregnancies. The Journal of nutrition, 133(5), 1732S-1736S.

Kippen, R. (2005). Counting Nineteenth-Century Maternal Deaths: The Case of Tasmania. Historical Methods: A Journal of Quantitative and Interdisciplinary History, 38(1), 14 - 25. 
Klasen, S. (1998). Marriage, bargaining, and intrahousehold resource allocation: Excess female mortality among adults during early German development, 1740-1860. Journal of Economic History, 58, 432-467.

Kok, J., \& Van Bavel, J. (2006). Stemming the tide. Denomination and religiousness in the Dutch fertility transition, 1845-1945. In R. Derosas \& F. W. A. Van Poppel (Eds.), Religion and the Decline of Fertility in the Western World (pp. 83-105). New York (NY): Springer.

Lepoeter, G. J., \& Teeuw, A. H. (2010). Marinus Nathanaël de Broekert, heel- en vroedmeester. Een verloskundige praktijk op het Zeeuwse platteland (1824-1871); weergave, analuyse, beschouwingen. apelle/Dordrecht: G.J. Lepoeter.

Loudon, I. (1986). Medical care and the general practitioner 1750-1850. Oxford: Clarendon Press.

Loudon, I. (1992). Death in childbirth: an international study of maternal care and maternal mortality 1800-1950. Oxford: Clarendon Press.

Neurdenburg, M. G. (1925). De levensduur van den Nederlandschen geneesheer. Nederlands Tijdschrift voor Geneeskunde, 69, 2819-2821.

Noordam, D. J. (1986). Leven in Maasland. Een hoogontwikkelde plattelandssamenleving in de achttiende en het begin van de negentiende eeuw. Hilversum: Verloren.

Paping, R., \& Tassenaar, V. (2007). The Consequences of the Potato Disease in the Netherlands 18451860: a Regional Approach In R. Paping, E. Vanhaute \& C. O'Grada (Eds.), When the Potato Failed. Causes and Effects of the Last European Subsistence Crisis, 1845-1850 (pp. 149-183). Turnhout: Brepols Publishers.

Perrenoud, A. (1981). Surmortalité féminine et condition de la femme (XVIIe-XIX siècles). Une vérification empirique. Annales de Démographie Historique, 89-104.

Persant Snoep, J. (1853). Verloskundige bijdragen. Middelburg: J.K. de Regt.

Prillevitz, J. C. (1909). Eenige mededeelingen omtrent mijne 42-jarige praktijk op verloskundig gebied, van af 1864 tot 1869 te Geervliet en daarna te Maarssen en omstreken tot 1907. Nederlandsch Tijdschrift voor Verloskunde en Gynaecologie, 19, 1-27.

Ramirez, G., Grimes, R., Annegers, J. F., Davis, B. R., \& Slater, C. H. (1990). Occupational physical activity and other risk factors for preterm birth among US Army primigravidas. American journal of Public Health, 80(6), 728-730.

Ronsmans, C., \& Campbell, O. (1998). Short Birth Intervals Don't Kill Women: Evidence from Matlab, Bangladesh. Studies in Family Planning, 29(3), 282-290

Rutten, W. J. M. J. (1985). Mortaliteit en medicalisering. Een regionaal-differentiele analyse van de sterfte zonder geneeskundige behandeling in Nederland (ca 1870-1900). Holland, 17(2), 131160.

Schofield, R. (1986). Did the mothers really die? Three centuries of maternal mortality in The World We Have Lost. In L. Bonfield, R. M. Smith \& K. Wrightson (Eds.), The World We Have Gained: Histories of Population and Social Structure (Vol. 231-260). Oxford: Basil Blackwell.

Shepherd, J. R., Schoonheim, M., Tian-Yun, C., \& Kok, J. (2011). Maternal mortality in Taiwan and the Netherlands, 1850-1945. In T. Engelen, J. R. Shepherd \& Y. Wen-shan (Eds.), Death at Opposite Ends of the Eurasian Continent: Mortality Trends in Taiwan and the Netherlands 1850-1945 (pp. 229-273). Amsterdam: Amsterdam University Press.

Shorter, E. (1982). A history of women's bodies. New York: Basic Books.

Smulders, A. J. (1962). Verloskundige hulp in vier huisartsenpraktijken uit de vorige eeuw. Huisarts en wetenschap, 5, 290-297.

Stanton, C., Hobcraft, J., Hill, K. H., Kodjogbe, N., Mapeta, W. T., Munene, F., et al. (2001). Every death counts: measurement of maternal mortality via a census. Bulletin of the World Health Organization, 79, 657-664. 
Starmans, J. H. (1930). Verloskunde en kindersterfte in Limburg. Folklore: Geschiedenis: Heden. Maastricht: Uitgeversmaatschappij Gebroeders van Aelst.

Treffers, P. E. (2009). Geschiedenis. Geboortedaling eind 19e en eerste helft 20e eeuw Coïtus interruptus belangrijkste vorm van anticonceptie. Ned Tijdschr Geneeskd., 153, B44.

Van Daalen, R. (1993). Family change and continuity in the Netherlands: Birth and childbed in text and art. In E. Abraham-Van der Mark (Ed.), Successful Home Birth and Midwivery: The Dutch Model (pp. 77-94). Amsterdam: Het Spinhuis.

Van de Putte, B., \& Miles, A. (2005). A class scheme for historical occupational data. The analysis of marital mobility in industrial cities in 19th century Flanders and England. Historical Methods, 38(2), 61-92.

Van der Waals. (1987).

van Lieburg, M. J. (1991). Jelle Banga (1786-1877): Notulist van de 19de-eeuwse genees- en verloskunde in een Friese provinciestad. Rotterdam: Erasmus Publishing.

van Lieburg, M. J., \& Kloosterman, G. J. (1987). Mother and Child Were Saved: The Memoirs (1693-1740) of the Frisian Midwife Catharina Schrader. Amsterdam: Rodopi.

Van Lieburg, M. J., \& Marland, H. (1989). Midwife regulation, education, and practice in the Netherlands during the nineteenth century. Medical History, 33, 296-317.

Van Poppel, F. (2004). De confrontatie met de dood: sterfte van vrouwen en van mannen in Nederland 1850-2002. In M. Altena, C. Bouw, M. Broekhans, W. Cappers, E. Van Nederveen Meerkerk, J. Reynaerts \& W. Ruberg (Eds.), Moordmeiden en schone slaapsters. Beleving en verbeelding van vrouwen en de dood (pp. 107-132). Amsterdam: Aksant.

Van Poppel, F., \& Ekamper, P. (2010). Historische ontwikkeling van de sterfte in Nederland. In A. H. P. Luijben \& G. J. Kommer (Eds.), Tijd en toekomst; deelrapport van de VTV 2010 Van gezond naar beter. RIVM-rapport 270061008 (pp. 20-25). Houten: Bohn Stafleu Van Loghum.

Van Poppel, F., Jonker, M., \& Mandemakers, K. (2005). Differential Infant and Child Mortality in three Dutch Regions, 1812-1909. Economic History Review, 58(2), 272-309.

Van Poppel, F., Van Dalen, H. P., \& Walhout, E. (2009). Diffusion of a social norm: tracing the emergence of the housewife in the Netherlands, 1812-1922. The Economic History Review, 62(1), 99-127.

Van Poppel, F. W. A. (1985). Late fertility decline in the Netherlands: the influence of religious denomination, socio-economic group and region. European journal of population 1(4), 347-373.

Van Tussenbroek, C. (1911). De ontwikkeling der aseptische verloskunde in Nederland. Haarlem: Bohn.

Vandenbroeke, C., Van Poppel, F., \& Van der Woude, A. M. (1984). Le développement séculaire de la mortalité aux jeunes âges dans le territoire du Bénélux. Annales de Démographie Historique, 1983, 257-289.

Verdoorn, J. A. (1965). Volksgezondheid en sociale ontwikkeling. Beschouwingen over het gezondheidswezen te Amsterdam in de 19e eeuw. Utrecht: Het Spectrum.

Ward, P. (2003). Perinatal Mortality in Utrecht, The Netherlands, 1880-1940. Economics and Human Biology, 1(3), 379-398.

Wintle, M. (2000). An Economic and Social History of the Netherlands, 1800-1920. Demographic, Economic and Social Transition. Cambridge: Cambridge University Press.

World Health Organisation. (1997). The sisterhood method for estimating maternal mortality: Guidance notes for potential users: World Health Organisation, Department of Reproductive Health and Research.

World Health Organisation. (2012). Maternal mortality: Fact sheet No. 348. Retrieved 7 Oct. 2012, 2012

World Health Organization. (2004). International Classification of Diseases (10 ed.). Geneva: World Health Organization. 
World Health Organization. (2012). The WHO application of ICD-10 to deaths during pregnancy, childbirth and puerperium: ICD MM. Geneva: World Health Organization.

Tables

Table 1. Summary statistics for Groningen, Drenthe, and Zeeland

\begin{tabular}{|c|c|c|c|}
\hline & Groningen & Drenthe & Zeeland \\
\hline Number of births between 1846-1902 & 260,112 & 169,577 & 311,306 \\
\hline $\begin{array}{l}\text { Number of maternal deaths } 1846-\mathrm{Feb} \\
11,1903\end{array}$ & 1,804 & 1,330 & 2,231 \\
\hline Number of births per marriage & 4.17 & 3.94 & 5.09 \\
\hline Average birth interval in days & 922.30 & 946.87 & 747.36 \\
\hline $\begin{array}{l}\text { Average female age at marriage, in } \\
\text { years }\end{array}$ & 24.63 & 24.45 & 24.12 \\
\hline Percent of infant deaths per total births & $11.82 \%$ & $10.29 \%$ & $15.93 \%$ \\
\hline Percent of stillbirths per total births & $4.08 \%$ & $4.64 \%$ & $4.39 \%$ \\
\hline $\begin{array}{l}\text { Average age at death for married } \\
\text { women, in years }\end{array}$ & 66.31 & 64.81 & 65.49 \\
\hline $\begin{array}{l}\text { Percent of women ages } 16+\text { in paid } \\
\text { employment in } 1849 *\end{array}$ & $34.04 \%$ & $40.62 \%$ & $52.21 \%$ \\
\hline $\begin{array}{l}\text { Most common source of paid } \\
\text { employment } 1849^{*}\end{array}$ & Day workers & Farmers & Day workers \\
\hline $\begin{array}{l}\text { Percent of women ages } 16-50 \text { in paid } \\
\text { employment in } 1899^{*}\end{array}$ & $25.88 \%$ & $21.81 \%$ & $32.19 \%$ \\
\hline $\begin{array}{l}\text { Most common source of paid } \\
\text { employment } 1899^{*}\end{array}$ & Servants & Servants & Farm business \\
\hline $\begin{array}{l}\text { Doctors per population (men and } \\
\text { women, all ages) } 1849^{*}\end{array}$ & $\begin{array}{l}857: 1 \\
\text { people/doctors }\end{array}$ & $\begin{array}{l}\text { 1235:1 } \\
\text { people/doctors }\end{array}$ & $\begin{array}{l}735: 1 \\
\text { people/doctors }\end{array}$ \\
\hline Midwives per females aged $16-50$ & $1232: 1$ & 1281:1 & $1572: 1$ \\
\hline $1899 *$ & women/midwife & women/midwife & women/midwife \\
\hline
\end{tabular}

*Sources: Volkstellingen 1795-1971. (1849). Uitkomsten der derde tienjarige volkstelling in het Koningrijk der Nederlanden op den negentienden November 1849. Retrieved September, 2012, from http://www.volkstellingen.nl/ \& Volkstellingen 1795-1971. (1899). Uitkomsten der achtste tienjaarlijksche volkstelling in het Koninkrijk der Nederlanden gehouden op den een en dertigsten December 1899. Retrieved September, 2012, from http://www.volkstellingen.nl/ Note: the employment categories changed between 1849 and 1899. 
Table 2. Summary statistics

\begin{tabular}{|c|c|c|c|c|}
\hline Variable & Mean & $\begin{array}{r}\text { Standard } \\
\text { deviation }\end{array}$ & Min & $\operatorname{Max}$ \\
\hline Pregnancy-related death & .0072403 & .0847812 & 0 & 1 \\
\hline $\begin{array}{l}\text { Average days under } \\
\text { observation (until death or } \\
\text { censorship) }\end{array}$ & 41.77 & 2.80 & .01 & 42 \\
\hline Age of mother at birth of child & 31.45 & 6.05 & 16.13 & 50.00 \\
\hline Birth interval & 851.71 & 516.36 & 252 & 9830 \\
\hline Parity & 3.82 & 2.68 & 1 & 22 \\
\hline Stillbirth & .04 & .20 & 0 & 1 \\
\hline Twins or multiples & .01 & .12 & 0 & 1 \\
\hline Stillbirth in prior pregnancy & .03 & .18 & 0 & 1 \\
\hline $\begin{array}{l}\text { Twins or multiples in prior } \\
\text { pregnancy }\end{array}$ & .01 & .10 & 0 & 1 \\
\hline Pregnancy in spring & .25 & .44 & 0 & 1 \\
\hline Pregnancy in summer & .23 & .42 & 0 & 1 \\
\hline Pregnancy in fall & .25 & .44 & 0 & 1 \\
\hline Pregnancy in winter & .26 & .44 & 0 & 1 \\
\hline Unskilled laborer & .50 & .50 & 0 & 1 \\
\hline Semiskilled laborer & .10 & .31 & 0 & 1 \\
\hline Skilled laborer & .14 & .35 & 0 & 1 \\
\hline Farmer & .13 & .33 & 0 & 1 \\
\hline Middle class, not farmer & .11 & .32 & 0 & 1 \\
\hline Elite & .01 & .11 & 0 & 1 \\
\hline Occupation unknown & .01 & .09 & 0 & 1 \\
\hline Price of rye in year of delivery & 6.58 & 1.61 & 3.94 & 10.72 \\
\hline $\begin{array}{l}\text { Price of rye in year prior to } \\
\text { delivery }\end{array}$ & 6.60 & 1.60 & 3.94 & 10.72 \\
\hline Groningen & .35 & .48 & 0 & 1 \\
\hline Drenthe & .23 & .42 & 0 & 1 \\
\hline Zeeland & .42 & .49 & 0 & 1 \\
\hline Year & 1876.30 & 15.95 & 1846 & 1902 \\
\hline
\end{tabular}

Total number of births under observation from 1846 to $1902=740,995$ 
Table 3. Two-way tabulation of proportion of observed biological risk factors and maternal mortality.

\begin{tabular}{|c|c|c|c|c|c|}
\hline & $\begin{array}{c}\text { Proportion } \\
\text { women who } \\
\text { survive } \\
\text { childbirth } \\
\end{array}$ & $\begin{array}{c}\text { Proportion } \\
\text { women who } \\
\text { die in } \\
\text { childbirth }\end{array}$ & $\begin{array}{l}\text { Difference } \\
\text { in } \\
\text { observed } \\
\text { means }\end{array}$ & $\begin{array}{c}\text { Lower } \\
95 \% \mathrm{CI} \\
\text { for mean } \\
\end{array}$ & $\begin{array}{c}\text { Upper } \\
95 \% \mathrm{CI} \\
\text { for mean }\end{array}$ \\
\hline \multicolumn{6}{|l|}{ Birth interval } \\
\hline $7-24 \mathrm{mo}$ & 49.43 & 49.48 & -0.05 & -0.02 & 0.02 \\
\hline $24-75 \mathrm{mo}$ & 48.29 & 47.73 & 0.56 & -0.02 & 0.02 \\
\hline $75 \mathrm{mo}+$ & 2.28 & 2.79 & -0.51 & 0.00 & 0.00 \\
\hline \multicolumn{6}{|l|}{ Parity } \\
\hline 1 & 21.36 & 22.52 & -1.16 & -0.01 & 0.01 \\
\hline $2-7$ & 68.36 & 62.67 & 5.69 & -0.01 & 0.01 \\
\hline $8+$ & 10.27 & 14.82 & -4.55 & -0.01 & 0.01 \\
\hline \multicolumn{6}{|l|}{ Maternal age } \\
\hline under 20 & 1.02 & 0.62 & 0.4 & 0.00 & 0.00 \\
\hline $20-34$ & 69.7 & 59.94 & 9.76 & -0.01 & 0.01 \\
\hline $35+$ & 29.28 & 39.44 & -10.16 & -0.01 & 0.01 \\
\hline \multicolumn{6}{|l|}{ Stillbirth (index) } \\
\hline Live birth & 95.8 & 77.19 & 18.61 & -0.01 & 0.01 \\
\hline Stillbirth & 4.2 & 22.81 & -18.61 & -0.01 & 0.01 \\
\hline \multicolumn{6}{|l|}{ Twins (index) } \\
\hline Singleton & 98.59 & 95.71 & 2.88 & 0.00 & 0.00 \\
\hline Twins/multiples & 1.41 & 4.29 & -2.88 & 0.00 & 0.00 \\
\hline \multicolumn{6}{|l|}{ Stillbirth (prior) } \\
\hline Live birth & 96.68 & 94.05 & 2.63 & 0.00 & 0.00 \\
\hline Stillbirth & 3.32 & 5.95 & -2.63 & 0.00 & 0.00 \\
\hline \multicolumn{6}{|l|}{ Twins (prior) } \\
\hline Singleton & 98.93 & 98.56 & 0.37 & 0.00 & 0.00 \\
\hline Twins/multiples & 1.07 & 1.44 & -0.37 & 0.00 & 0.00 \\
\hline
\end{tabular}


Table 4. Two-way tabulation of proportion of observed sociological risk factors and maternal mortality.

\begin{tabular}{|c|c|c|c|c|c|}
\hline & $\begin{array}{l}\text { Proportion } \\
\text { women } \\
\text { who } \\
\text { survive } \\
\text { childbirth }\end{array}$ & $\begin{array}{l}\text { Proportion } \\
\text { women } \\
\text { who die in } \\
\text { childbirth }\end{array}$ & $\begin{array}{l}\text { Difference } \\
\text { in } \\
\text { observed } \\
\text { means }\end{array}$ & $\begin{array}{l}\text { Lower } \\
95 \% \text { CI for } \\
\text { mean }\end{array}$ & $\begin{array}{l}\text { Upper } \\
95 \% \text { CI for } \\
\text { mean }\end{array}$ \\
\hline \multicolumn{6}{|l|}{ Social class } \\
\hline Unskilled & 49.62 & 46.45 & 3.17 & -0.01 & 0.01 \\
\hline Semiskilled & 10.45 & 10.66 & -0.21 & -0.01 & 0.01 \\
\hline Skilled & 14.17 & 14.99 & -0.82 & -0.01 & 0.01 \\
\hline Farm & 12.52 & 15.51 & -2.99 & -0.01 & 0.01 \\
\hline Other middle & 11.3 & 10.2 & 1.1 & -0.01 & 0.01 \\
\hline Elite & 1.12 & 1.23 & -0.11 & 0.00 & 0.00 \\
\hline Unknown & 0.82 & 0.97 & -0.15 & 0.00 & 0.00 \\
\hline \multicolumn{6}{|l|}{ Decade } \\
\hline $1846-1855$ & 13.03 & 16.72 & -3.69 & -0.01 & 0.01 \\
\hline $1856-1865$ & 15.59 & 19.11 & -3.52 & -0.01 & 0.01 \\
\hline 1866-1875 & 18.5 & 19.85 & -1.35 & -0.01 & 0.01 \\
\hline 1876-1885 & 19.13 & 19.37 & -0.24 & -0.01 & 0.01 \\
\hline 1886-1895 & 19.23 & 16.33 & 2.9 & -0.01 & 0.01 \\
\hline 1896-1902 & 14.52 & 8.63 & 5.89 & -0.01 & 0.01 \\
\hline \multicolumn{6}{|l|}{ Season } \\
\hline Winter & 25.93 & 29.47 & -3.54 & -0.01 & 0.01 \\
\hline Spring & 25.46 & 27.25 & -1.79 & -0.01 & 0.01 \\
\hline Summer & 23.12 & 20.15 & 2.97 & -0.01 & 0.01 \\
\hline Fall & 25.49 & 23.13 & 2.36 & -0.01 & 0.01 \\
\hline \multicolumn{6}{|l|}{ Province } \\
\hline Groningen & 35.12 & 33.36 & 1.76 & -0.01 & 0.01 \\
\hline Drenthe & 22.9 & 24.79 & -1.89 & -0.01 & 0.01 \\
\hline Zeeland & 41.98 & 41.58 & 0.4 & -0.01 & 0.01 \\
\hline
\end{tabular}


Table 5. Distribution of time until maternal mortality

\begin{tabular}{lrr}
\hline $\begin{array}{l}\text { Time until } \\
\text { maternal } \\
\text { mortality }\end{array}$ & Frequency & \multicolumn{1}{c}{ Percent } \\
\hline 0-1 days & 1,223 & 22.8 \\
2-7 days & 1,457 & 27.16 \\
8-14 days & 1,155 & 21.53 \\
15-42 days & 1,530 & 28.52 \\
\hline
\end{tabular}

$\mathrm{N}=5,365$

Table 6. Proportion of maternal mortalities by days since delivery and parity

\begin{tabular}{rrrrr}
\hline \multicolumn{5}{c}{ Days until death } \\
\hline Parity & $0-1$ & $2-7$ & $8-14$ & $15-42$ \\
\hline 1 & 0.13 & 0.26 & 0.28 & 0.33 \\
2 & 0.19 & 0.28 & 0.22 & 0.31 \\
3 & 0.20 & 0.30 & 0.20 & 0.29 \\
4 & 0.23 & 0.28 & 0.21 & 0.28 \\
5 & 0.27 & 0.29 & 0.19 & 0.25 \\
6 & 0.28 & 0.25 & 0.17 & 0.29 \\
7 & 0.31 & 0.26 & 0.19 & 0.24 \\
8 & 0.33 & 0.26 & 0.16 & 0.26 \\
9 & 0.39 & 0.22 & 0.21 & 0.18 \\
10 & 0.29 & 0.26 & 0.15 & 0.30 \\
11 & 0.44 & 0.19 & 0.12 & 0.26 \\
12 & 0.38 & 0.30 & 0.23 & 0.10 \\
13 & 0.20 & 0.20 & 0.40 & 0.20 \\
14 & 0.48 & 0.10 & 0.24 & 0.19 \\
15 & 0.31 & 0.08 & 0.23 & 0.38 \\
16 & 0.00 & 0.67 & 0.33 & 0.00 \\
17 & 1.00 & 0.00 & 0.00 & 0.00 \\
18 & 0.00 & 1.00 & 0.00 & 0.00 \\
20 & 1.00 & 0.00 & 0.00 & 0.00 \\
\hline 741,792 & & & &
\end{tabular}

$\mathrm{N}=741,792$ 
Table 7. Proportion of maternal mortalities associated with a s stillbirth by decade

\begin{tabular}{ccc}
\hline \multicolumn{3}{c}{ If stillbirth in index pregnancy: } \\
\hline Decade & $\begin{array}{c}\text { no maternal } \\
\text { mortality }\end{array}$ & $\begin{array}{l}\text { maternal } \\
\text { mortality }\end{array}$ \\
\hline $1846-1855$ & 96.18 & 3.82 \\
$1856-1865$ & 96.01 & 3.99 \\
$1866-1875$ & 96.26 & 3.74 \\
$1876-1885$ & 96.08 & 3.92 \\
$1886-1895$ & 95.96 & 4.04 \\
$1896-1902$ & 96.88 & 3.12 \\
\hline
\end{tabular}

$\mathrm{N}=32,190$

Table 8. Proportion of maternal deaths by days since delivery and decade

\begin{tabular}{lcccr}
\hline & \multicolumn{4}{c}{ Days until death } \\
\hline Decade & $0-1$ & $2-7$ & $8-14$ & $15-42$ \\
\hline $1846-1855$ & 0.12 & 0.04 & 0.04 & 0.01 \\
$1856-1865$ & 0.14 & 0.04 & 0.03 & 0.01 \\
$1866-1875$ & 0.14 & 0.05 & 0.03 & 0.01 \\
$1876-1885$ & 0.17 & 0.04 & 0.04 & 0.01 \\
$1886-1895$ & 0.20 & 0.04 & 0.03 & 0.01 \\
$1896-1902$ & 0.24 & 0.04 & 0.03 & 0.01 \\
\hline
\end{tabular}

$\mathrm{N}=5,365$ 
Table 9. Poisson regression on maternal death, $\mathrm{N}=740,995$

\begin{tabular}{|c|c|c|c|}
\hline Variables & Model 1 & Model 2 & Model 3 \\
\hline \multicolumn{4}{|l|}{ Birth interval } \\
\hline $7-24 \mathrm{mo}$ & $1.11 * *$ & $1.11 * *$ & $1.13 * *$ \\
\hline $24-75 \mathrm{mo}$ (ref) & -- & -- & -- \\
\hline $75 \mathrm{mo}+$ & 1.01 & 1.03 & 1.06 \\
\hline \multicolumn{4}{|l|}{ Social class } \\
\hline Unskilled (ref) & & & -- \\
\hline Semiskilled & & & 1.06 \\
\hline Skilled & & & $1.11 *$ \\
\hline Farm & & & $1.31 * *$ \\
\hline Other middle & & & 0.96 \\
\hline Elite & & & 1.13 \\
\hline Unknown & & & 1.31 \\
\hline Maternal age & $1.04 * *$ & $1.07 * *$ & $1.04 * *$ \\
\hline Maternal age $^{\wedge}$ & & 1 & \\
\hline 2 & & & \\
\hline \multicolumn{4}{|l|}{ Parity } \\
\hline 1 & $1.50 * *$ & $1.52 * *$ & $1.44 * *$ \\
\hline $2-7$ (ref) & -- & -- & -- \\
\hline $8+$ & $1.10^{*}$ & 1.09 & $1.18 * *$ \\
\hline \multicolumn{4}{|l|}{ Index pregnancy } \\
\hline Twin/multiple & $1.58 * *$ & $1.58 * *$ & $1.57 * *$ \\
\hline Stillbirth & $5.75^{* *}$ & $5.75^{* *}$ & $5.72 * *$ \\
\hline \multicolumn{4}{|l|}{$\begin{array}{l}\text { Previous } \\
\text { pregnancy }\end{array}$} \\
\hline Twin/multiple & 1.15 & 1.15 & 1.14 \\
\hline Stillbirth & 1.13 & $1.13 *$ & 1.12 \\
\hline \multicolumn{4}{|l|}{ Province } \\
\hline Groningen & & & $0.87 * *$ \\
\hline Drenthe (ref) & & & -- \\
\hline Zeeland & & & $0.89 * *$ \\
\hline \multicolumn{4}{|l|}{ Season } \\
\hline Winter & & & -- \\
\hline Spring & & & 0.95 \\
\hline Summer & & & $0.79 * *$ \\
\hline Fall & & & $0.82 * *$ \\
\hline \multicolumn{4}{|l|}{ Decade } \\
\hline $1846-1855$ & & & $1.23 * *$ \\
\hline $1856-1865$ & & & $1.14 * *$ \\
\hline $1866-1875$ (ref) & & & -- \\
\hline 1876-1885 & & & 0.94 \\
\hline
\end{tabular}




\begin{tabular}{|c|c|c|c|}
\hline $\begin{array}{l}1886-1895 \\
1896-1902\end{array}$ & & & $\begin{array}{l}0.81 * * \\
0.58 * *\end{array}$ \\
\hline \multicolumn{4}{|l|}{$\begin{array}{l}\text { Parity*maternal } \\
\text { age }\end{array}$} \\
\hline parity $*<20$ & & 0.92 & \\
\hline parity*20-34 & & -- & \\
\hline (ref) & & & \\
\hline parity*35+ & & 1 & \\
\hline _cons & $0.00 * *$ & $0.00 * *$ & $0.00 * *$ \\
\hline $\mathrm{N}$ & 740995 & 740995 & 740995 \\
\hline LL & -30490.27 & -30488.764 & -30313.611 \\
\hline
\end{tabular}

Figures

Figure captions:

1. International comparison of maternal mortality rates per 10,000 births

2. Average number of children ever born per contracted marriage by province

3. Lexis diagram of data available for analysis

4. Maternal mortality rate by data source

5. Maternal mortality rate over time in all three provinces

6. Maternal mortality by province

7. Age- and parity-adjusted maternal mortality, direct standardization method 
Figure 1. International comparison of maternal mortality rates per 10,000 births

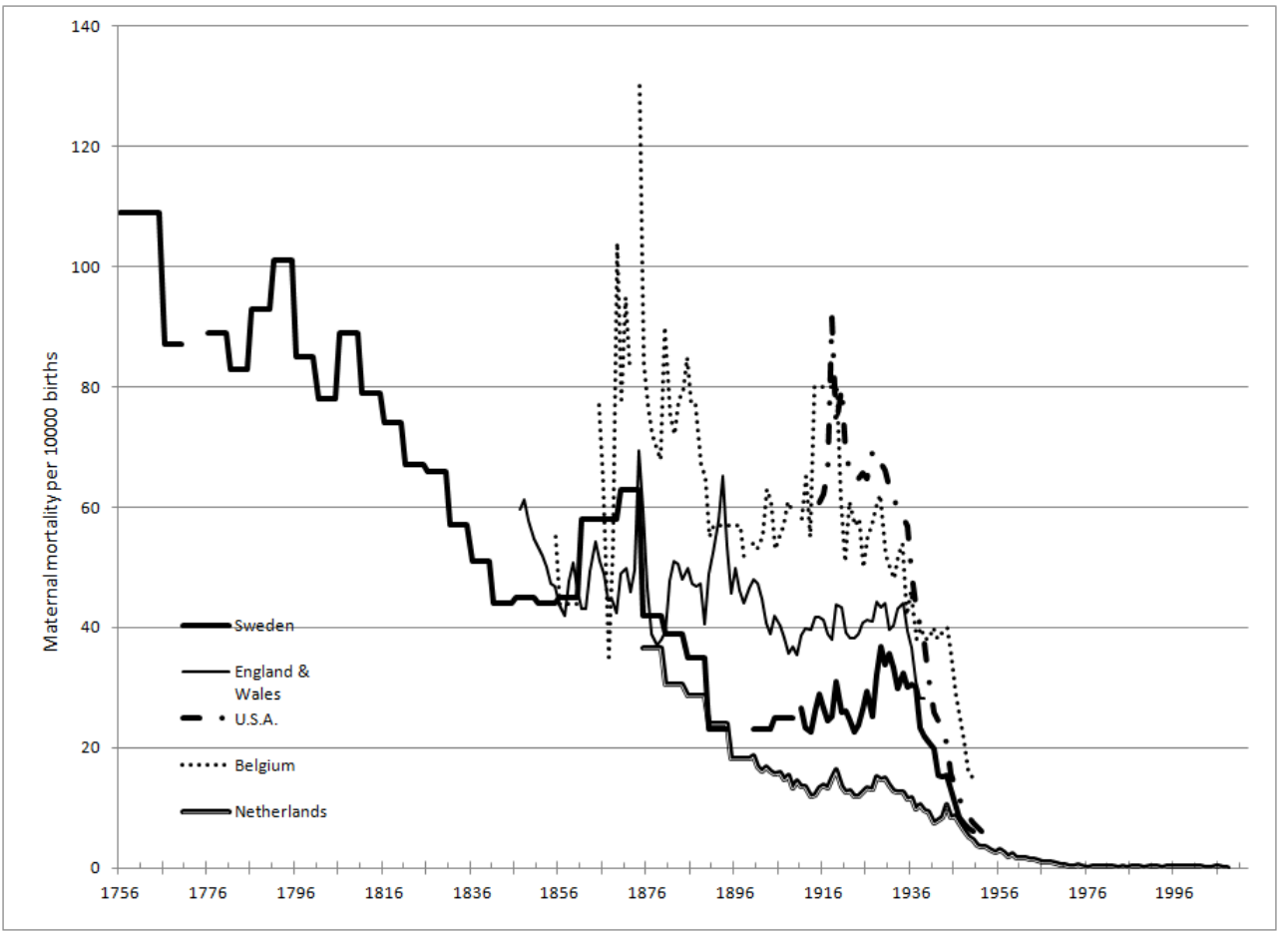

Source Sweden, England \& Wales, USA, and Belgium data: (Loudon 1992).

2. Average number of children ever born per contracted marriage by province

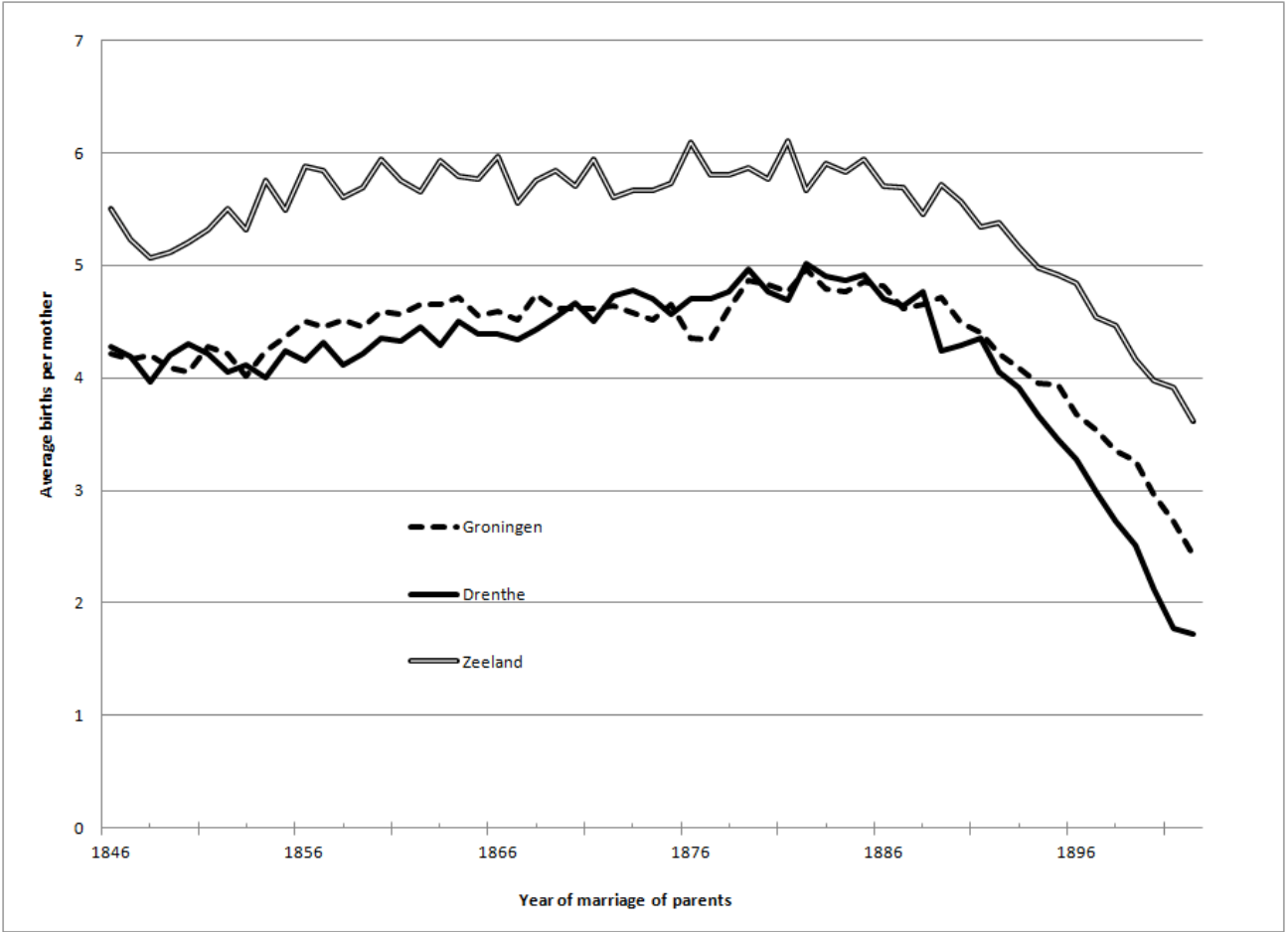


Figure 3. Lexis diagram of data available for analysis

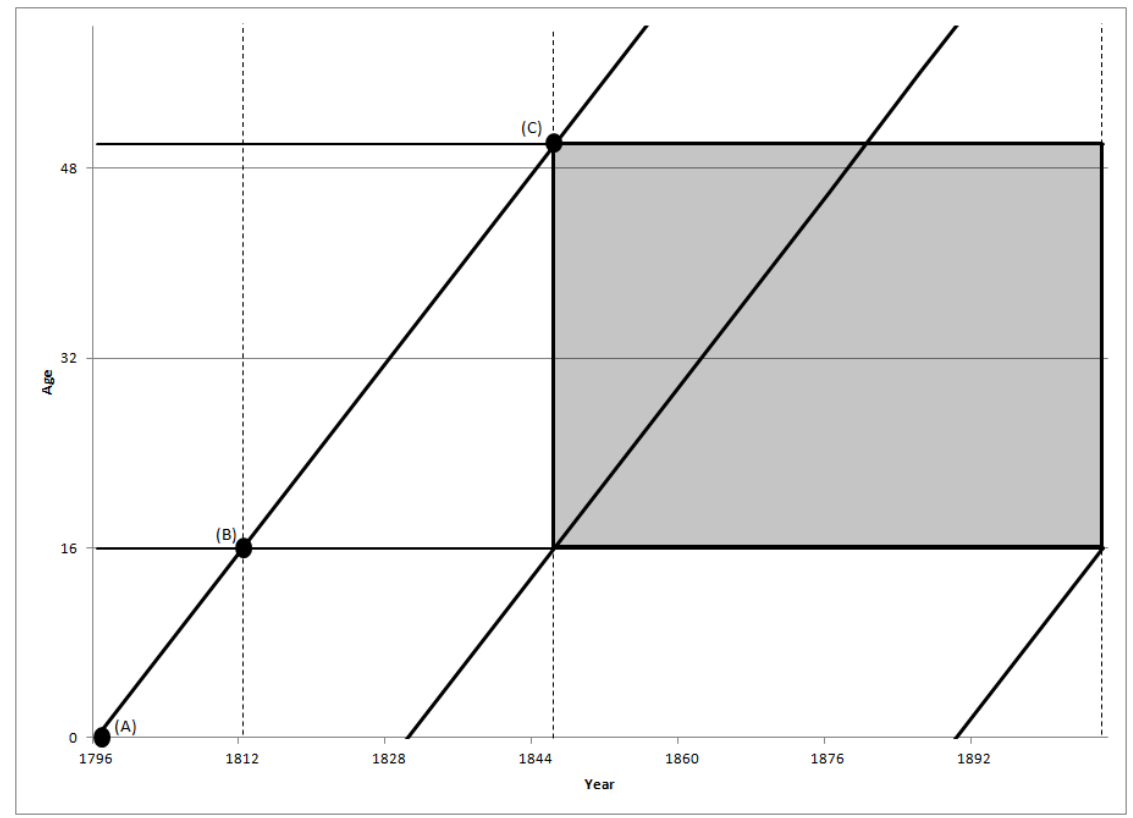

Figure 4. Maternal mortality rate by data source

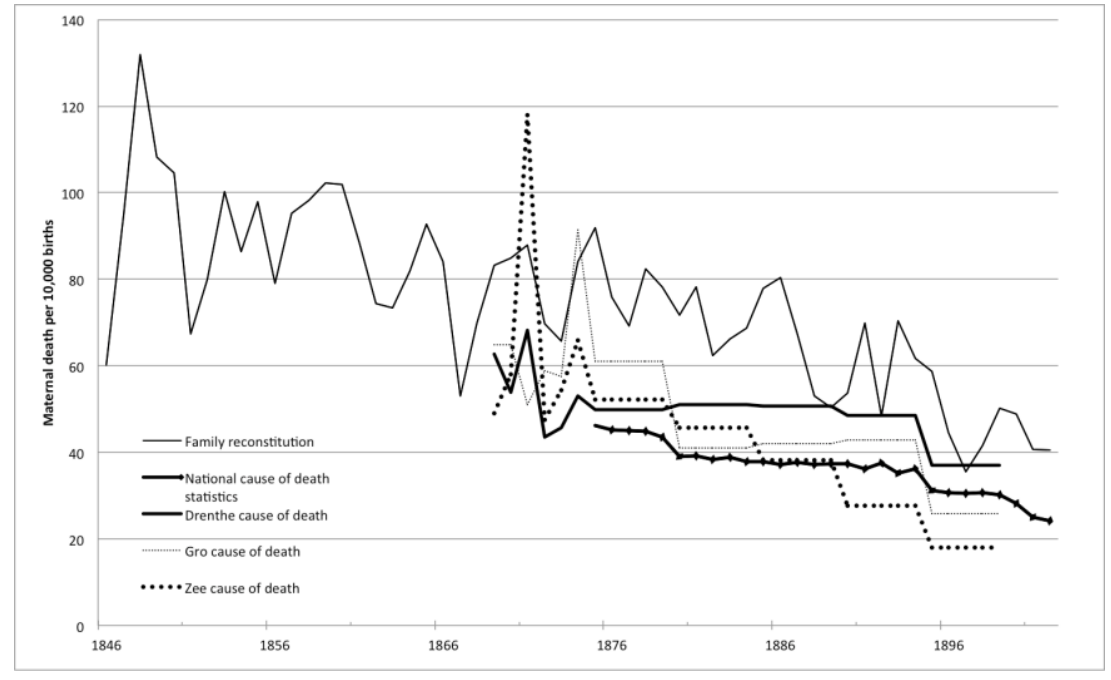

Source Drenthe, Groningen, and Zeeland cause of death statistics: Department van Binnenlansche Zaken. (18711883) Statistische bescheiden voor het Koningrijk der Nederlanden: Sterfte naar de oorzaken van den dood 18691874. 's-Gravenhage, the Netherlands: Van Weelden den Mingelen.

Source National cause of death statisics: Ministerie van Binnenlandse Zaken. (1882-1901) Vijfjarig overzicht van de sterfte naar den leeftijd en de oorzaken van den dood in elke gemeente van Nederland gedurend 1875-1902. 'sGravenhage, the Netherlands: Van Weelden den Mingelen. 
Figure 5. Maternal mortality rate over time in all three provinces

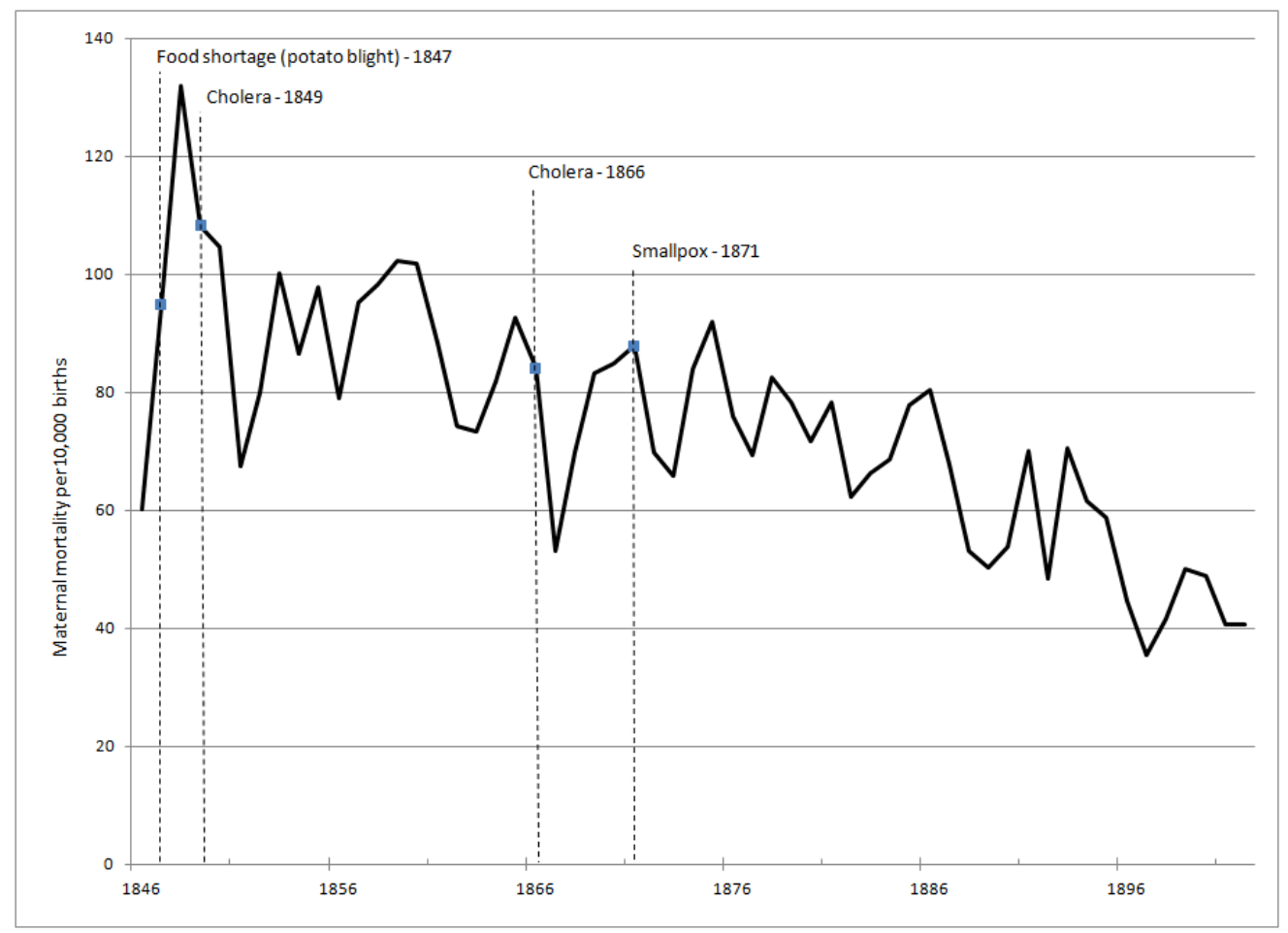

Figure 6 . Maternal mortality rate by province

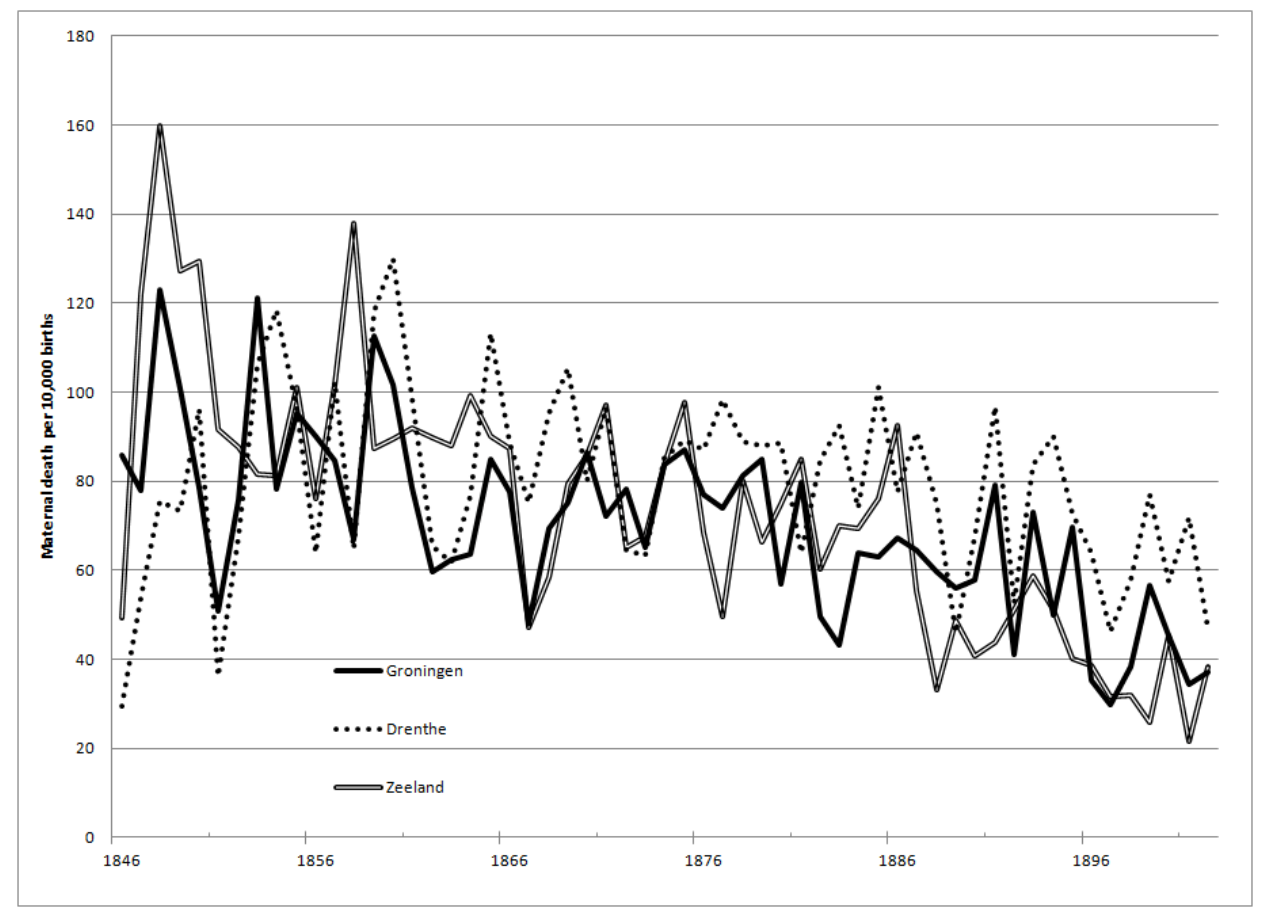


Figure 7. Age- and parity-adjusted maternal mortality, direct standardization method.

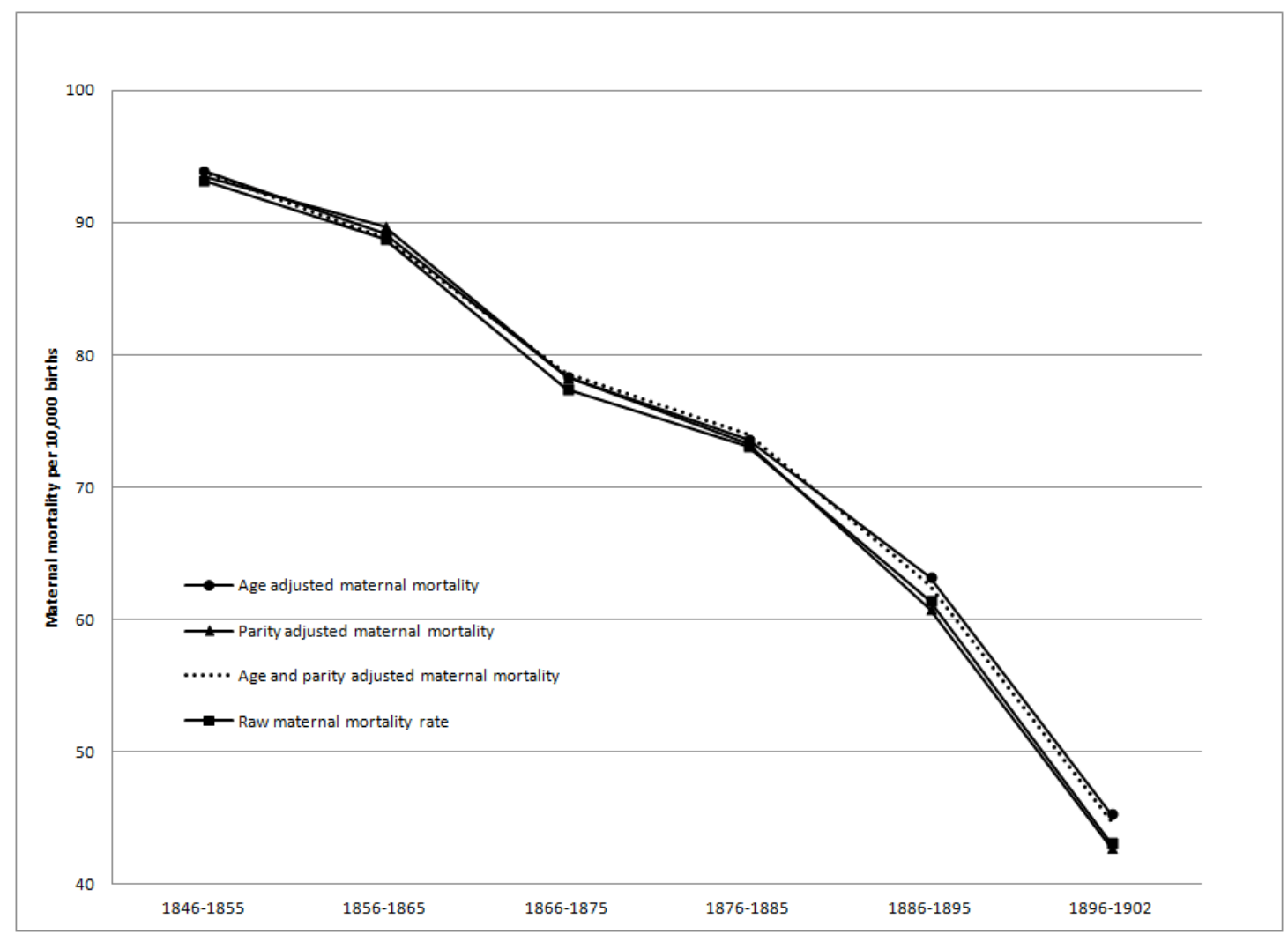

